\title{
Synthesis of Metal-Organic Frameworks by Continuous Flow
}

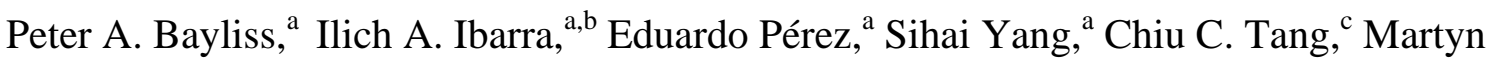
Poliakoff ${ }^{\mathrm{a} *}$ and Martin Schröder ${ }^{\mathrm{a} *}$

[a] School of Chemistry, University of Nottingham, University Park, NG7 2RD (UK)

[b] Instituto de Investigaciones en Materiales, Universidad Nacional Autónoma de México, Circuito Exterior s/n, CU, Del. Coyoacán, 04510, México D.F., Mexico

[c] Diamond Light Source, Harwell Science and Innovation Campus, Didcot, Oxfordshire, OX11 0DE, (UK)

[*] E-mail: Martyn.Poliakoff@nottingham.ac.uk; M.Schroder@nottingham.ac.uk; Fax: +44 1159513563

\section{Keywords}

Continuous process, flow chemistry, metal-organic framework, high temperature water, green chemistry, MIL-53, HKUST-1. 


\begin{abstract}
A continuous flow process for the synthesis of a metal-organic framework using only water as the reaction medium and requiring only short residence times is described. This affords a new route to scale-up of materials incorporating many of the principles of green chemistry. The process is demonstrated by the synthesis MIL-53(Al) via continuous flow reaction requiring only 5-6 minutes with a space time yield of $1300 \mathrm{~kg} \mathrm{~m}^{-3} \mathrm{~d}^{-1}$. We have demonstrated the synthesis of $500 \mathrm{~g}$ of MIL-53(Al) using this process, which can be scaled-up further by simply feeding further solutions of metal salt and ligand through the reactor. The product has a higher surface area and a better colour than a commercially produced sample of this MOF. In addition, a new and effective method for the extraction of terephthalic acid from within the pores of MIL-53(Al) using supercritical ethanol has been developed, representing a new methodology for activation and removal of substrates from porous hosts.
\end{abstract}

\title{
Introduction
}

Metal-organic frameworks (MOFs) are currently the focus of intense scientific interest due to their wide range of potential applications in gas storage ${ }^{1,2}$ and separation, ${ }^{3}$ catalysis, ${ }^{4,5}$ drug delivery, ${ }^{6-8}$ and as thermo-active, ${ }^{9}$ conducting ${ }^{10,11}$ and electronic ${ }^{12,13}$ materials. Of particular interest to us is the potential of MOFs to store and purify fuel and exhaust gases. ${ }^{14}$ For industrial scale applications, MOFs must not only possess the desired functionality and properties, but their synthesis and processing must be scalable at low cost to give products in high yield and purity. Increasing environmental awareness and commercial constraints mean that synthetic processes must be as green as possible, and water is thus an attractive solvent for the synthesis of MOFs. ${ }^{15,16}$

The most common methods for MOF synthesis are solvothermal batch reactions in Teflon-lined stainless steel bombs or glass pressure tubes. ${ }^{17-19}$ Long reactions times of several days are commonly used with slow heating and cooling rates using solvents such as N,N'dimethylformamide (DMF), which is a toxic mutagen and environmentally hazardous. ${ }^{20,21}$ Slow hydrothermal syntheses are typically carried out at temperatures up to $220{ }^{\circ} \mathrm{C}$, while microwave, ${ }^{22,23}$ sonication and mechanochemical ${ }^{24,25}$ syntheses involve shorter reaction times in some cases. However, for microwave and alternative methods of synthesis to be cost effective for scale-up, they need to have clear benefits over conventional heating routes. ${ }^{26,27}$ Continuous flow synthesis of MOFs has been demonstrated previously in elegant studies 
using interfacial synthesis to produce hollow MOF capsules on a small scale, ${ }^{28}$ and utilising rapid solvent mixing. ${ }^{29,30}$ Significantly, however, these methods still make use of organic solvents such as 1 -octanol, ${ }^{28} \mathrm{DMF}^{29}$ and $\mathrm{EtOH} .{ }^{30}$ One of our objectives is to completely eliminate the use of toxic/organic solvents by using high temperature water (HTW). In previous reports water has been successfully use as the reaction solvent for the synthesis of MOF materials. ${ }^{15,16,31}$ Herein we confirm that HTW can be used to reduce the reaction times from days to minutes in order to prepare porous materials rapidly and cleanly with excellent potential for scale-up, particularly under continuous flow. We demonstrate this methodology by using HTW to produce MIL-53(Al), a benchmark MOF that combines thermal stability with porosity ${ }^{32}$ and adsorption selectivity. ${ }^{33}$ We combine this with a new strategy for removal of guest molecule in MIL-53(Al) using supercritical EtOH.

\section{Results and discussion}

We have previously reported the use of HTW for the batch synthesis of MOFs, but the reaction generally required $48 \mathrm{hr}$ for completion. ${ }^{15}$ We have now developed this further such that the batch reaction of $\mathrm{Al}\left(\mathrm{NO}_{3}\right)_{3}$ with terephthalic acid $\left(\mathrm{H}_{2} \mathrm{~L}^{1}\right)$ in $\mathrm{HTW}$ at $250{ }^{\circ} \mathrm{C}$ yielded porous MIL-53(Al) in 10 min. A molar ratio for $\mathrm{Al}\left(\mathrm{NO}_{3}\right)_{3}: \mathrm{H}_{2} \mathrm{~L}^{1}$ of $2: 3$ was used with concentrations of $0.04 \mathrm{~mol} \mathrm{dm}^{-3}$ and $0.06 \mathrm{~mol} \mathrm{dm}^{-3}$, respectively. The identity and composition of the MIL-53(Al) produced by this method was confirmed by powder X-ray diffraction (PXRD) and characterised further by thermal gravimetric analysis (TGA) and gas adsorption isotherms. Given that this represents a reduction in reaction time from 3 days to 10 min., ${ }^{34}$ we reasoned that this new approach could be developed further towards scale-up via continuous processing. However, $\mathrm{H}_{2} \mathrm{~L}^{1}$ is insoluble in cold water and is thus difficult to use in a continuous flow process using water. Thus, a trial batch reaction was carried out using disodium terephthalate $\left(\mathrm{Na}_{2} \mathrm{~L}^{1}\right)$, which is water-soluble. This yielded MIL-53(Al) identical to the experiments using $\mathrm{H}_{2} \mathrm{~L}^{1}$ (Scheme 1). Reactions in batch were then carried out to establish whether the reaction temperature could be reduced whilst still using reaction times of 10 minutes. Batch reactions at $200{ }^{\circ} \mathrm{C}$ afforded product that is less crystalline as confirmed by PXRD which shows significant peak broadening, while reactions at $150{ }^{\circ} \mathrm{C}$ afforded almost no MOF product and much of the $\mathrm{H}_{2} \mathrm{~L}^{1}$ could be isolated as unreacted starting material.

A schematic of our apparatus developed for the continuous reaction is shown in (Figure 1). Aqueous solutions of $\mathrm{Al}\left(\mathrm{NO}_{3}\right)_{3}$ and $\mathrm{Na}_{2} \mathrm{~L}^{1}$ are pumped by means of HPLC pumps (Gilson 306, $10 \mathrm{ml}$ pump heads), and these solutions are mixed with another stream of water preheated to $300^{\circ} \mathrm{C}$ before entering the tubular reactor (ID 0.370 ”, volume $20.8 \mathrm{ml}$ ). The 
temperature of the reactor is kept constant using resistance heaters and a temperature controller (Eurotherm 2216L), and downstream, the mixture is cooled by a heat exchanger. The solid product is recovered by a Tee filter $(0.5 \mu \mathrm{m})$ and after filtration the liquid byproduct stream enters a Back Pressure Regulator (BPR). The use of filtration enables the product to be recovered dry, and minimises the chance of BPR malfunctions. Two sets of filters and BPRs are installed in parallel to facilitate continuous operation of the system.

Reaction of $\mathrm{Al}\left(\mathrm{NO}_{3}\right)_{3}$ with $\mathrm{Na}_{2} \mathrm{~L}^{1}$ in the continuous reactor in a $1: 1$ ratio at $0.05 \mathrm{~mol} \mathrm{dm}^{-3}$ concentration gave high quality MIL-53(Al), and running the reaction for 20 minutes gave $0.5 \mathrm{~g}$ of product as a white powder (yield: $86 \%$ crude, $59 \%$ after removal of terephthalic acid from pores, based on $\mathrm{Al}$ utilisation and product $\left.\left[\mathrm{AlOH}\left(\mathrm{L}^{1}\right)\right]_{\mathrm{n}}\right)$. Both the assynthesised batch and continuous flow products are microcrystaline and match known MIL53(Al) phases. MIL-53(Al) is known to exhibit a breathing effect and phase transitions induced by heating or by uptake and removal of guest species. ${ }^{34-38}$ Furthermore, the assynthesised phase, MIL-53(Al)ta, contains uncoordinated $\mathrm{H}_{2} \mathrm{~L}^{1}$ trapped within the pores and this requires removal to maximise its porosity. Usually removal of trapped $\mathrm{H}_{2} \mathrm{~L}^{1}$ is achieved via calcination involving heating at $330{ }^{\circ} \mathrm{C}$ for 3 days ${ }^{34}$ or washing with DMF. ${ }^{35,36}$ In order to remove this uncoordinated ligand we developed a new procedure involving extraction of the product with supercritical ethanol $(\mathrm{scEtOH})$ at $250^{\circ} \mathrm{C}$ and $100 \mathrm{bar}$ for $2 \mathrm{hr}$. This method effectively removes the uncoordinated $\mathrm{H}_{2} \mathrm{~L}^{1}$ from within the pores without decomposing the material. The extraction rig (Figure 2) used liquid ethanol at a flow rate of $0.5 \mathrm{ml} \mathrm{min}^{-1}$, a back pressure of 100 bar with the first batch reactor held at $250{ }^{\circ} \mathrm{C}$ for $2 \mathrm{~h}$. Removal of inpore $\mathrm{H}_{2} \mathrm{~L}^{1}$ could be readily monitored by by PXRD (Figure S3), TGA (Figure S14) and ATRFTIR (Figure S16).

The removal of $\mathrm{H}_{2} \mathrm{~L}^{1}$ causes a phase change to a more open structure, MIL-53(Al)op, and this converts to the hydrated form, MIL-53(Al)hy, upon adsorption of water. The major phase using HTW in batch reaction is MIL-53(Al)ta. In continuous flow, the same phase is isolated but MIL-53(Al)hy is also present in the product (Figure 3a). PXRD analysis of products obtained from batch and by continuous flow reactions shows no peaks for $\gamma-\mathrm{AlO}(\mathrm{OH}), \mathrm{H}_{2} \mathrm{~L}^{1}$ or other MOF phases. High resolution PXRD were recorded for a desolvated sample in which $\mathrm{H}_{2} \mathrm{~L}^{1}$ had been removed, and the recorded pattern matches very well with the MIL-53(Al)op phase (Figure 3b). Refinement of the PXRD patterns confirms the bulk purity of the sample (Figures S7 and S8). TGA demonstrates that the as-synthesised batch product MIL-53(Al)ta has thermal stability up to $540{ }^{\circ} \mathrm{C}$ and contains 0.8 equivalents of free $\mathrm{H}_{2} \mathrm{~L}^{1}$ (Figure 4). This is consistent with the thermal behaviour reported by Loiseau $e t$ 
$a l .{ }^{34}$ where 0.7 equivalents of free $\mathrm{H}_{2} \mathrm{~L}^{1}$ was observed in the material. The product formed by continuous process shows similar thermal stability and contains 0.41 equivalents of free $\mathrm{H}_{2} \mathrm{~L}^{1}$ as determined by TGA.

MIL-53(Al) prepared at $250{ }^{\circ} \mathrm{C}$ using batch and continuous flow processes was treated with scEtOH to remove free $\mathrm{H}_{2} \mathrm{~L}^{1}$ from the pores (see ESI for details). This was followed by activation of the sample at $125^{\circ} \mathrm{C}$ under vacuum overnight, and the $\mathrm{N}_{2}$ adsorption was recorded for samples. The isotherms are type I as expected for this microporous material and the maximum uptakes (at $0.95 \mathrm{P} / \mathrm{P}_{0}$ ) for the batch and continuous flow samples were $289 \mathrm{~cm}^{-3} \mathrm{~g}^{-1}$ and $296 \mathrm{~cm}^{-3} \mathrm{~g}^{-1}$, respectively (Figure 5). BET surface areas for the batch and continuous flow samples were $1097 \mathrm{~m}^{2} \mathrm{~g}^{-1}$ and $919 \mathrm{~m}^{2} \mathrm{~g}^{-1}$, respectively, consistent with previously reported values for MIL-53(Al) of between $1270 \mathrm{~m}^{2} \mathrm{~g}^{-1}$ and $933 \mathrm{~m}^{2} \mathrm{~g}^{-1} \cdot 32,34,39$ A significant feature of MIL-53 materials is their framework flexibility upon gas loading. Importantly, the desolvated MIL-53(Al) sample produced via continuous flow in HTW exhibits the same expected framework phase transition upon $\mathrm{CO}_{2}$ adsorption (Figure S17). Therefore, this HTW method does not alter the nature of the MOF material produced suggesting wider applicability of continuous flow to produce other MOFs. However, it is important to select the right reaction conditions to produce a highly porous material. The effect of temperature on the surface area and gas uptake of the material produced was investigated by performing the reactions between 200 and $300{ }^{\circ} \mathrm{C}$. These results, summarised in Table 1, confirm that the optimum temperature for this system is $250{ }^{\circ} \mathrm{C}$.

The real test of any 'green' process is whether it can be scaled up to produce commercially useful quantities of product. Therefore in collaboration with an industrial partner we have tested our synthesis of MIL-53(Al) using a larger scale reactor. With a flow rate for $\mathrm{Na}_{2} \mathrm{~L}^{1}$ of $400 \mathrm{ml} \mathrm{min}^{-1}$ mixed with a heated flow of $\mathrm{Al}\left(\mathrm{NO}_{3}\right)_{3}$ at $200 \mathrm{ml} \mathrm{min}^{-1}$, more than $500 \mathrm{~g}$ of MIL-53(Al) were produced as an aqueous slurry in $4 \mathrm{hr}$. After drying of the material, the resulting MOF powder is pure white in appearance (Figure 6) and after removal by calcination of $\mathrm{H}_{2} \mathrm{~L}^{1}$ from the pores the material has a surface area of $1010 \mathrm{~m}^{2} \mathrm{~g}^{-1}$ similar to that of the lab-scale sample and nearly double the $553 \mathrm{~m}^{2} \mathrm{~g}^{-1}$ of a commercially supplied sample of the same MOF (see ESI). ${ }^{40}$ This scale of reaction corresponds to approximately 1 metric tonne per annum. The waste from this process include salts such as $\mathrm{NaNO}_{3}$ but these can be readily removed from the effluent. ${ }^{41,42}$ Another possibility to be explored is the use of a terephthalic acid saturator after the preheater to avoid the generation of sodium salts or by the substitution of $\mathrm{Al}\left(\mathrm{NO}_{3}\right)_{3}$ by $\mathrm{Al}(\mathrm{OAc})_{3}$ as acetate waste would be less hazardous. 
However at the current scale of MOF manufacturing, disposal of these wastes does not pose a significant problem.

In order to demonstrate further the scope of the above methods, the MOF material HKUST-1 was synthesised in high temperature ethanol as the reaction solvent, first in batch and then using the continuous process. HKUST-1 has been synthesised previously in continuous flow, ${ }^{28,29,43}$ and using ethanol in batch. ${ }^{44}$ The process reported here combines the use of the green solvent ethanol and a continuous process, and PXRD of the isolated materials from this process confirms the formation of HKUST-1 (Figure 7). As both the trimesic acid ligand $\left(\mathrm{H}_{3} \mathrm{~L}^{2}\right)$ and $\mathrm{Cu}\left(\mathrm{NO}_{3}\right)_{2}$ are soluble in ethanol the use of ligand salts was not required in this case. No free ligand was recovered with the MOF material and so a second purification step was not necessary. The material produced by continuous process had a surface area of $1554 \mathrm{~m}^{2} \mathrm{~g}^{-1}$, a maximum $\mathrm{N}_{2}$ uptake of $417 \mathrm{~cm}^{3} \mathrm{~g}^{-1}\left(0.95 \mathrm{P} / \mathrm{P}_{0}\right)$, and a pore volume of $0.62 \mathrm{~cm}^{3} \mathrm{~g}^{-1}$ (Figure $\mathrm{S} 15$ ). The space time yield of HKUST-1 in this process was $730 \mathrm{~kg} \mathrm{~m}^{-3} \mathrm{~d}^{-1}$.

\section{Conclusions}

In summary, a rapid and green method for the synthesis of MIL-53(Al) with an excellent potential for scale-up has been developed in which HTW is used in continuous flow. We have thus far produced MIL-53(Al) in up to $500 \mathrm{~g}$ scale via continuous flow, and the utilisation of a green solvent combined with abundant, low-cost metal and ligand enhance this potential to form multi-kg quantities. A green synthesis for $\mathrm{H}_{2} \mathrm{~L}^{1}$ using $\mathrm{HTW}$ is already established $^{45-47}$ and so a complete process from the synthesis of the ligand to final MOF product can be envisaged using HTW. Although some MOFs including MIL-53(Al) are commercially available, their current price is too high for them to be used in most applications. MIL-53(Al) is currently sold at $£ 2440-3455$ for $500 \mathrm{~g} .{ }^{40}$ To reduce this cost, more productive processes are required, and the space time yield, defining the mass of product produced per unit volume per unit time, is an important parameter for comparing processes. Reported values for commercially-available MOFs correspond to space time yields of between 20 and $>300 \mathrm{~kg} \mathrm{~m}^{-3} \mathrm{~d}^{-1}$ with MIL-53(Al) at $160 \mathrm{~kg} \mathrm{~m}^{-3} \mathrm{~d}^{-1}$. ${ }^{49}$-51 The space time yield for our continuous flow process for MIL-53(Al) reported here is significantly higher at $1300 \mathrm{~kg} \mathrm{~m}^{-3} \mathrm{~d}^{-1}$. Thus, the rapid synthesis of MOFs in HTW represents a greener method with potential for further investigation and possible commercialisation. 


\section{Experimental}

All reagents and solvents were used as received from commercial suppliers without further purification for both the batch and the continuous reactions.

\section{Synthesis of MIL-53(Al)}

Batch Synthesis: The synthesis of $\left\{\left[\mathrm{AlOH}\left(\mathrm{L}^{1}\right)\right] \cdot 0.8 \mathrm{H}_{2} \mathrm{~L}^{1}\right\}_{\mathrm{n}}, \mathrm{MIL}-53(\mathrm{Al})$ in water was carried out in a high-pressure stainless steel batch reactor (10 $\mathrm{ml}$ of internal volume). The reactor was located in an aluminium heating block surrounded by an electric band heater $(1 \mathrm{~kW})$ with a cooling jacket for rapid cooling. Details of the device have been previously reported. ${ }^{48}$ $\mathrm{Al}\left(\mathrm{NO}_{3}\right)_{3} \cdot 9 \mathrm{H}_{2} \mathrm{O}(112.9 \mathrm{mg}, 0.301 \mathrm{mmol}), \mathrm{H}_{2} \mathrm{~L}^{1}(75.0 \mathrm{mg}, 0.451 \mathrm{mmol})$ and water $(5.0 \mathrm{ml})$ were transferred into the reactor, and the reaction mixture rapidly heated by preheating the aluminium block $20^{\circ} \mathrm{C}$ higher than the desired temperature. The time required to reach the target reaction temperature is ca $5 \mathrm{~min}$, and the system was kept at the target reaction temperature for $10 \mathrm{~min}$ and rapidly quenched using the cooling jacket. The product was recovered by filtration, washed with water and acetone, and dried in air. The reaction gave a white powder with a yield of $54 \mathrm{mg}(91 \%)$ and a purified yield after scEtOH extraction of 39 $\operatorname{mg}(66 \%)$.

Continuous Process: General conditions involved a flow rate of $1.0 \mathrm{ml} \mathrm{min} \mathrm{m}^{-1}$ to give a total flow rate of $3.0 \mathrm{ml} \mathrm{min}{ }^{-1}$ of water. The pressure of the system (230 bar), and the temperature of the preheater and the reactor $\left(300{ }^{\circ} \mathrm{C}\right.$ and $250{ }^{\circ} \mathrm{C}$, respectively) were set to the desired values. Once the temperatures were stable, the streams were changed to metal salt and ligand solutions and the flows passed through Filter 1 for $20 \mathrm{~min}$. The three way valve was then switched to Filter 2 and next batch of product collected for 20 min, while product in Filter 1 was collected and a new filter inserted. After $20 \mathrm{~min}$, the three way valve was switched back to Filter 1, new reaction conditions set and while the product in Filter 2 was collected and the filter, further product was collected in Filter 1. This process can be repeated for as long as sufficient metal salt and carboxylate ligand can be supplied.

\section{Synthesis of HKUST-1}

The same procedure was used for the synthesis of HKUST-1 but ethanol instead of water was used (see Supplementary Details). For the synthesis of HKUST-1, the pressure of the system, temperature of the preheater and the reactor set were to $75 \mathrm{bar}, 300{ }^{\circ} \mathrm{C}$ and $200{ }^{\circ} \mathrm{C}$ respectively, resulting in a 5.1 min residence time. Feed concentrations of $0.15 \mathrm{~mol} \mathrm{dm}{ }^{-3}$ and $0.10 \mathrm{~mol} \mathrm{dm}{ }^{-3}$ were used for the $\mathrm{Cu}\left(\mathrm{NO}_{3}\right)_{2}$ and trimesic acid $\left(\mathrm{H}_{3} \mathrm{~L}^{2}\right)$, and 
the concentration in the reactor was $0.05 \mathrm{~mol} \mathrm{dm}^{-3}$ and $0.03 \mathrm{~mol} \mathrm{dm}^{-3}$, respectively. After 15 minutes the reaction yielded $0.536 \mathrm{~g}$ of HKUST-1 as a blue powder. The powder contained $31.3 \%$ solvent as determined by TGA and so the yield of dry MOF was $63 \%$ with the product defined as $\left[\mathrm{Cu}_{3}\left(\mathrm{C}_{6} \mathrm{H}_{3}\left(\mathrm{CO}_{2}\right)_{3}\right]_{\mathrm{n}}\right.$.

\section{Acknowledgments}

We thank EPSRC and the University of Nottingham for support, and the CVCP and University of Nottingham (to EP) for funding. We gratefully acknowledge the receipt of an ERC Advanced Grant (to MS), a University of Nottingham 2012 EPSRC Doctoral Prize (to PAB), funding from CONACyT (to IAI), and a Leverhulme Trust Early Career Research Fellowship and a Nottingham Research Fellowship (to SY). We thank Diamond Light Source for access to Beamline I11.

\section{References}

1. S. Q. Ma and H. C. Zhou, ChemComm., 2010, 46, 44-53.

2. X. Lin, N. R. Champness and M. Schröder, Topics in Current Chem., 2010, 293, $35-76$

3. J.-R. Li, R. J. Kuppler and H.-C. Zhou, Chem. Soc. Rev., 2009, 38, 1477 - 1504.

4. J. Lee, O. K. Farha, J. Roberts, K. A. Scheidt, S. T. Nguyen and J. T. Hupp, Chem. Soc. Rev., 2009, 38, 1450-1459.

5. L. Ma and W. Lin, Topics in Current Chem., 2010, 293, 175-205

6. N. J. Hinks, A. C. McKinlay, B. Xiao, P. S. Wheatley and R. E. Morris, Microporous and Mesoporous Mat., 2010, 129, 330-334.

7. R. C. Huxford, J. Della Rocca and W. Lin, Curr. Op. in Chem. Biol., 2010, 14, 262-268.

8. A. C. McKinlay, R. E. Morris, P. Horcajada, G. Férey, R. Gref, P. Couvreur and C. Serre, Angew. Chem. Int. Ed., 2010, 49, 6260-6266.

9. F. Jeremias, A. Khutia, S. K. Henninger and C. Janiak, J. Mat. Chem., 2012, 22, 10148-10151.

10. D. Umeyama, S. Horike, M. Inukai, Y. Hijikata and S. Kitagawa, Angew. Chem. Int. Ed., 2011, 50, 11706-11709.

11. J. A. Hurd, R. Vaidhyanathan, V. Thangadurai, C. I. Ratcliffe, I. L. Moudrakovski and G. K. H. Shimizu, Nature Chem., 2009, 1, 705-710.

12. N. Roques, V. Mugnaini and J. Veciana, Topics in Current Chem., 2010, 293, 207-258

13. M. Kurmoo, Chem. Soc. Rev., 2009, 38, 1353-1379.

14. M. P. Suh, H. J. Park, T. K. Prasad and D.-W. Lim, Chem. Rev., 2012, 112, 782835. 
15. I. A. Ibarra, P. A. Bayliss, E. Perez, S. Yang, A. J. Blake, H. Nowell, D. R. Allan, M. Poliakoff and M. Schröder, Green Chem., 2012, 14, 117-122.

16. S. Yang, J. Sun, A. J. Ramirez-Cuesta, S. K. Callear, I. W. F. David, D. P. Anderson, R. Newby, A. J. Blake, J. E. Parker, C. C. Tang and M. Schröder, Nature Chem., 2012, 4, 887-894.

17. Y. Yan, S. Yang, A. J. Blake, W. Lewis, E. Poirier, S. A. Barnett, N. R. Champness and M. Schröder, ChemComm., 2011, 47, 9995-9997.

18. M. Kim, J. A. Boissonnault, C. A. Allen, P. V. Dau and S. M. Cohen, Dalton, 2012, 41, 6277-6282.

19. X. Lin, A. J. Blake, C. Wilson, X. Z. Sun, N. R. Champness, M. W. George, P. Hubberstey, R. Mokaya and M. Schröder, J. Am. Chem. Soc., 2006, 128, 10745 10753.

20. T. H. Kim and S. G. Kim, Safety Health Work, 2011, 2, 97-104.

21. D.-B. Shieh, C.-C. Chen, T.-S. Shih, H.-M. Tai, Y.-H. Wei and H.-Y. Chang, Chem-Bio. Interactions, 2007, 165, 211-219.

22. S. H. Jhung, J.-H. Lee, P. M. Forster, G. Férey, A. K. Cheetham and J.-S. Chang, Chemistry - Eur. J., 2006, 12, 7899-7905.

23. J. Klinowski, F. A. Almeida Paz, P. Silva and J. Rocha, Dalton, 2011, 40, 321 330.

24. J. Rocha, L. D. Carlos, F. A. A. Paz and D. Ananias, Chem. Soc. Rev., 2011, 40, 926-940.

25. S. L. James, C. J. Adams, C. Bolm, D. Braga, P. Collier, T. Friscic, F. Grepioni, K. D. M. Harris, G. Hyett, W. Jones, A. Krebs, J. Mack, L. Maini, A. G. Orpen, I. P. Parkin, W. C. Shearouse, J. W. Steed and D. C. Waddell, Chem. Soc. Rev., 2012, 41, 413-447.

26. T. N. Glasnov and C. O. Kappe, Macromolecular Rapid Commun., 2007, 28, 395410.

27. M. Damm, T. N. Glasnov and C. O. Kappe, Org. Proc. Res. \& Dev., 2009, 14, 215-224.

28. R. Ameloot, F. Vermoortele, W. Vanhove, M. B. J. Roeffaers, B. F. Sels and D. E. De Vos, Nature Chem., 2011, 3, 382-387.

29. M. Gimeno-Fabra, A. S. Munn, L. A. Stevens, T. C. Drage, D. M. Grant, R. J. Kashtiban, J. Sloan, E. Lester and R. I. Walton, ChemComm., 2012, 48, 1064210644.

30. K.-J. Kim, Y. J. Li, P. B. Kreider, C.-H. Chang, N. Wannenmacher, P. K. Thallapally and H.-G. Ahn, ChemComm., 2013, 49, 11518-11520.

31. R. Lee, J. Kim and W.-S. Ahn, Korean J. Chem. Eng., 2013, 30, 1667-1680.

32. G. Férey, M. Latroche, C. Serre, F. Millange, T. Loiseau and A. PercheronGuegan, ChemComm., 2003, 2976-2977.

33. V. Finsy, L. Ma, L. Alaerts, D. E. De Vos, G. V. Baron and J. F. M. Denayer, Microporous and Mesoporous Mat., 2009, 120, 221-227.

34. T. Loiseau, C. Serre, C. Huguenard, G. Fink, F. Taulelle, M. Henry, T. Bataille and G. Férey, Chemistry - Eur. J., 2004, 10, 1373-1382. 
35. E. Haque, N. A. Khan, J. E. Lee and S. H. Jhung, Chemistry - Eur. J., 2009, 15, 11730-11736.

36. P. Rallapalli, D. Patil, K. Prasanth, R. Somani, R. Jasra and H. Bajaj, J. Porous Mat., 2010, 17, 523-528.

37. Y. Liu, J.-H. Her, A. Dailly, A. J. Ramirez-Cuesta, D. A. Neumann and C. M. Brown, J. Am. Chem. Soc., 2008, 130, 11813-11818.

38. M. Vougo-Zanda, J. Huang, E. Anokhina, X. Wang and A. J. Jacobson, Inorg. Chem., 2008, 47, 11535-11542.

39. B. Panella, K. Hönes, U. Müller, N. Trukhan, M. Schubert, H. Pütter and M. Hirscher, Angew. Chem. Int. Ed., 2008, 47, 2138-2142.

40. Basolite ${ }^{\circledR}$ A100 produced by BASF | Sigma-Aldrich, http://www.sigmaaldrich.com/catalog/product/aldrich/688738?lang=en\&region=G $\underline{\mathrm{B}}$, http://www.sigmaaldrich.com/catalog/product/aldrich/688738?lang=en\&region=U $\underline{\mathrm{S}}$

http://www.sigmaaldrich.com/catalog/product/aldrich/688738?lang=de\&region=D E, Accessed 09/01/2014.

41. L. F. Wu, P. C. Chen, A. P. Huang and C. M. Lee, Bioresource Technol., 2012, 113, 14-18.

42. A. Bhatnagar and M. Sillanpää, Chem. Eng. J., 2011, 168, 493-504.

43. K.-J. Kim, Y. J. Li, P. B. Kreider, C.-H. Chang, N. Wannenmacher, P. K. Thallapally and H.-G. Ahn, ChemComm., 2013, 49, 11518-11520.

44. M. Hartmann, S. Kunz, D. Himsl, O. Tangermann, S. Ernst, A. Wagener, Langmuir , 2008, 24, 8634-8642.

45. J. B. Dunn and P. E. Savage, Green Chem. 2003, 5, 649-655.

46. E. Perez, J. Fraga-Dubreuil, E. Garcia-Verdugo, P. A. Hamley, W. B. Thomas, D. Housley, W. Partenheimer and M. Poliakoff, Green Chem., 2011, 13, 2389-2396.

47. E. Perez, J. Fraga-Dubreuil, E. Garcia-Verdugo, P. A. Hamley, M. L. Thomas, C. Yan, W. B. Thomas, D. Housley, W. Partenheimer and M. Poliakoff, Green Chem., 2011, 13, 2397-2407.

48. N. Stock and S. Biswas, Chem. Rev., 2012, 112, 933-969.

49. A. U. Czaja, N. Trukhan and U. Müller, Chem. Soc. Rev., 2009, 38, 1284-1293.

50. U. Mueller, M. Schubert, F. Teich, H. Puetter, K. Schierle-Arndt and J. Pastre, J. Mat. Chem., 2006, 16, 626-636.

51. L. M. Dudd, E. Venardou, E. Garcia-Verdugo, P. Licence, A. J. Blake, C. Wilson and M. Poliakoff, Green Chem., 2003, 5, 187-192. 


\section{Figure and Legends}

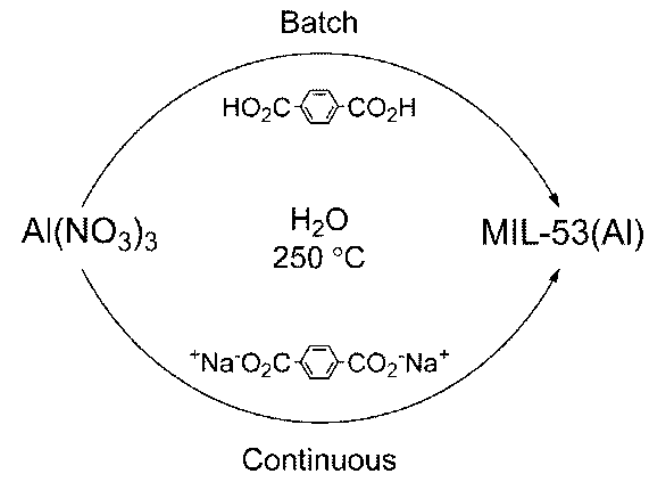

Scheme 1 Reaction scheme for batch reaction and continuous flow processes for the synthesis of MIL-53(Al).

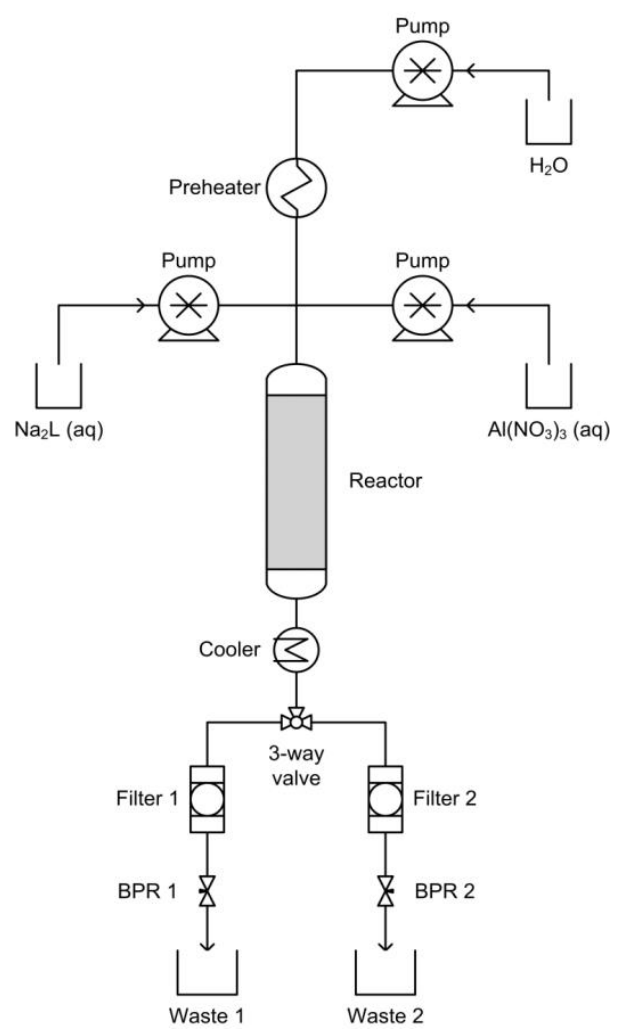

Figure 1 Schematic of the continuous process rig. The grey section represents the heated section of the reactor. 


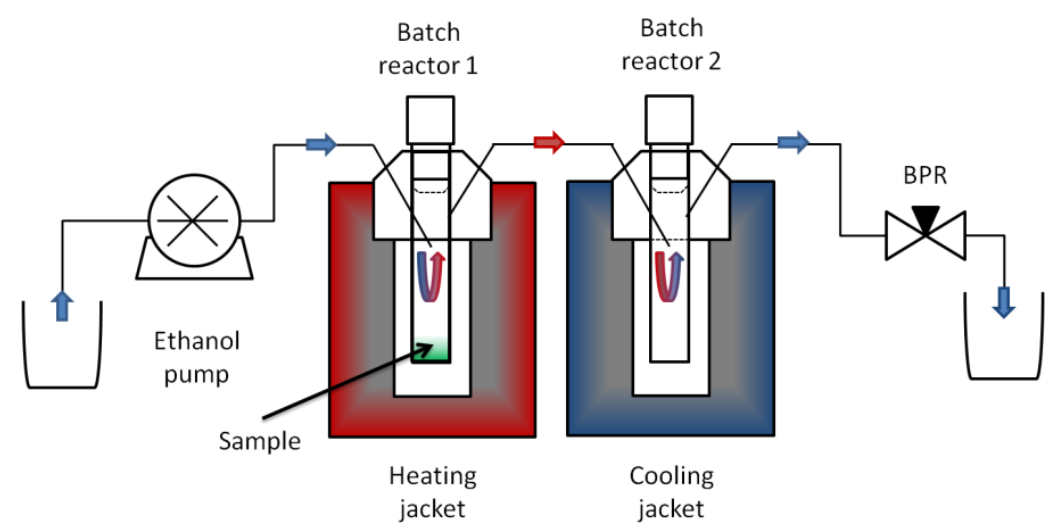

Figure 2 Diagram of extraction rig comprising of a pump, two batch reactors in series $\left(1^{\text {st }}\right.$ heated, $2^{\text {nd }}$ cooled) and a back pressure regulator. Arrows indicate the flow direction; red and blue highlight heated and cold areas, respectively.
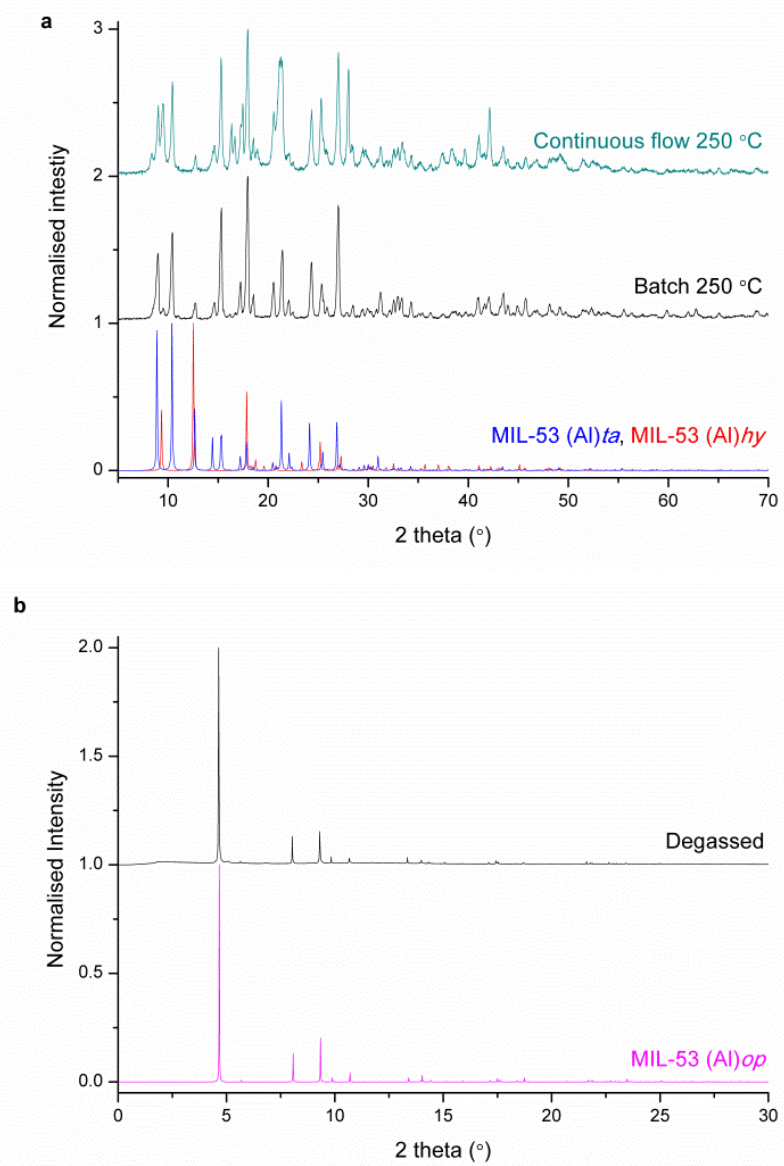

Figure 3 (a) PXRD patterns of as-synthesised MIL-53(Al) produced in batch (black) and continuous flow (green) at $250{ }^{\circ} \mathrm{C}$, and simulated pattern for MIL-53(Al)ta (blue) and MIL-53(Al)hy (red). (b) High resolution PXRD ( $\lambda=0.827107 \AA$ ) of desolvated MIL-53(Al) produced in batch at $250{ }^{\circ} \mathrm{C}$ and treated with scEtOH (black) and simulated pattern for MIL-53(Al)op (pink). 


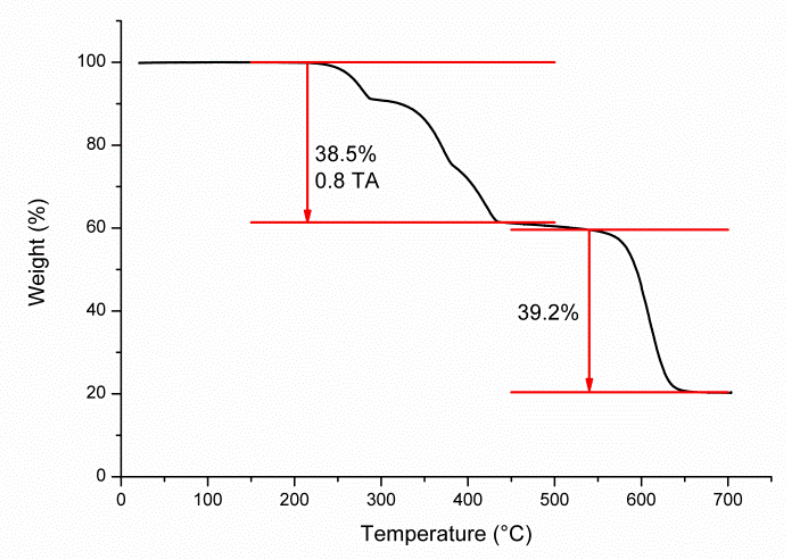

Figure 4 TGA of as-synthesised MIL-53(Al) material prepared by batch reaction $\left(250{ }^{\circ} \mathrm{C}\right)$ at a heating rate of $5^{\circ} \mathrm{C} \mathrm{min}{ }^{-1}$. The first step of $38.5 \%$ between $215^{\circ} \mathrm{C}$ and $440{ }^{\circ} \mathrm{C}$ is the loss of in-pore $\mathrm{H}_{2} \mathrm{~L}^{1}$ and the second step of $39.2 \%$ between $500{ }^{\circ} \mathrm{C}$ to $690{ }^{\circ} \mathrm{C}$ is loss of coordinated ligand and decomposition of the material.

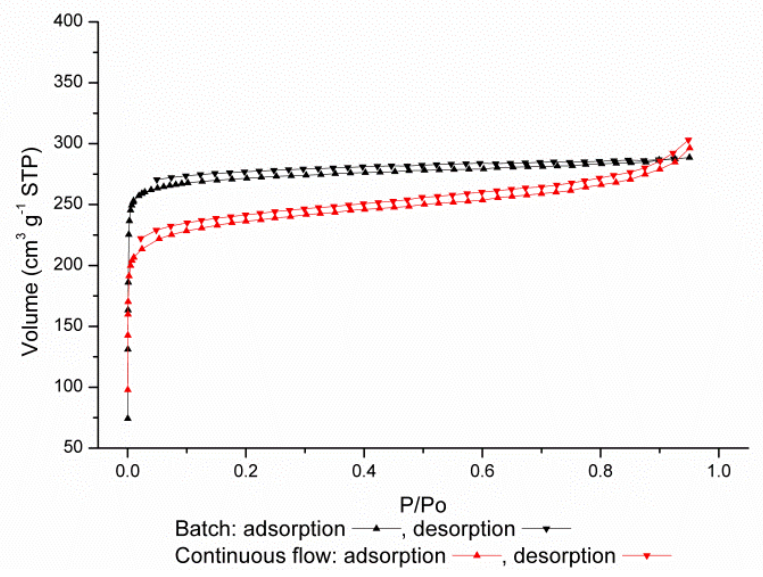

Figure 5 Comparison of $\mathrm{N}_{2}$ isotherms at $77 \mathrm{~K}$ for activated MIL-53(Al) prepared by batch (black) and continuous flow (red).

Table 1 Summary of surface areas and $\mathrm{N}_{2}$ uptake at $77 \mathrm{~K}$ for MIL-53(Al) produced by continuous flow at temperatures between 225 and $300{ }^{\circ} \mathrm{C}$.

\begin{tabular}{|c|c|c|}
\hline $\begin{array}{c}\text { Synthesis } \\
\text { temperature }\left({ }^{\circ} \mathrm{C}\right)\end{array}$ & $\begin{array}{c}\text { BET surface } \\
\text { area }\left(\mathrm{m}^{2} \mathrm{~g}^{-1}\right)\end{array}$ & $\begin{array}{c}\text { Uptake at } \mathrm{p} / \mathrm{p}_{0}= \\
0.95\left(\mathrm{~cm}^{3} \mathrm{~g}^{-1}\right)\end{array}$ \\
\hline 225 & 459 & 223.5 \\
\hline 250 & 919 & 296.4 \\
\hline 275 & 804 & 258.7 \\
\hline 300 & 566 & 204.5 \\
\hline
\end{tabular}




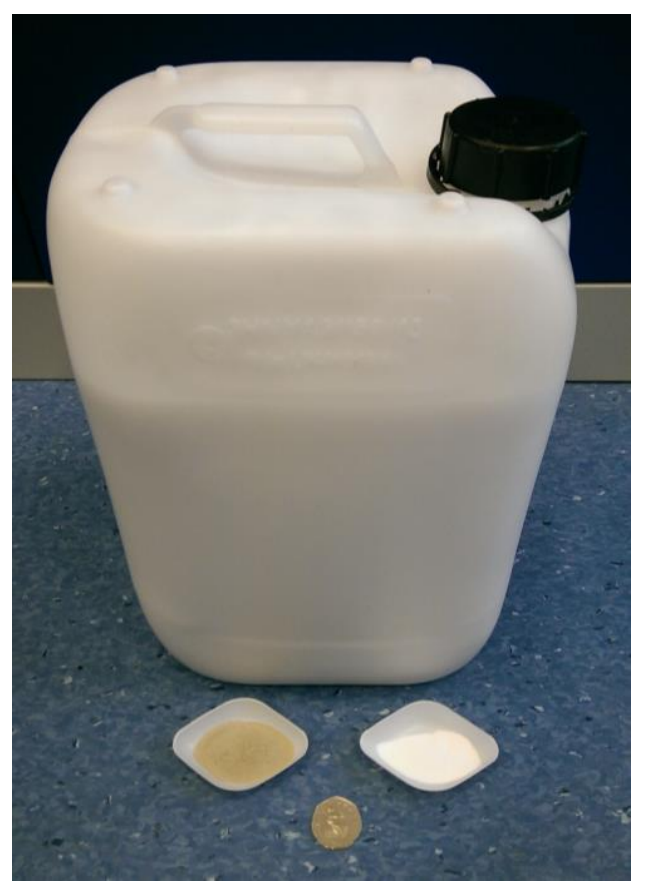

Figure 6 Photograph of the barrel containing a suspension of MIL-53(Al) formed by continuous flow in our scaled-up reaction (centre), together with a commercial sample (bottom left) and dried MIL-53(Al) from the barrel (bottom right). A fifty pence piece is shown for scale (bottom centre).

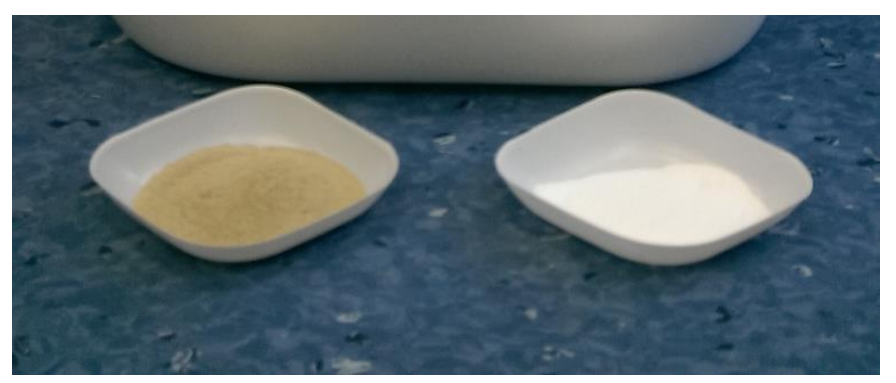

Figure 7 Photograph of a commercial sample of MIL-53(Al) (left), and our scaled-up material prepared by continuous flow (right). 


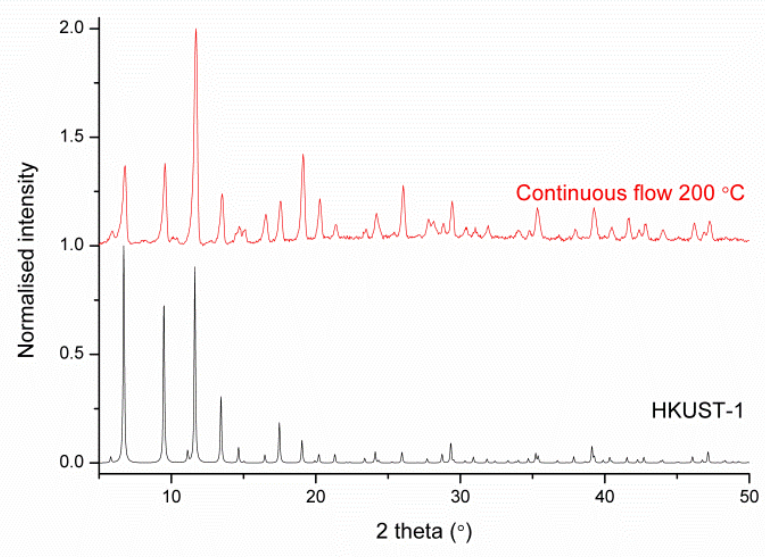

Figure 7 Comparison of PXRD for as-synthesised HKUST-1 material produced by continuous flow reaction at $200{ }^{\circ} \mathrm{C}$ (red), and the simulated pattern of HKUST-1 (black). 


\section{Table of Contents Graphic}

Continuous flow synthesis of MIL-53(Al) can be achieved via continuous flow reaction in only 5-6 minutes with a space time yield of $1300 \mathrm{~kg} \mathrm{~m}^{-3} \mathrm{~d}^{-1}$. In addition, a new and effective method for the extraction of terephthalic acid from within the pores of MIL-53(Al) using supercritical ethanol has been developed, representing a new methodology for activation and removal of substrates from within porous hosts.

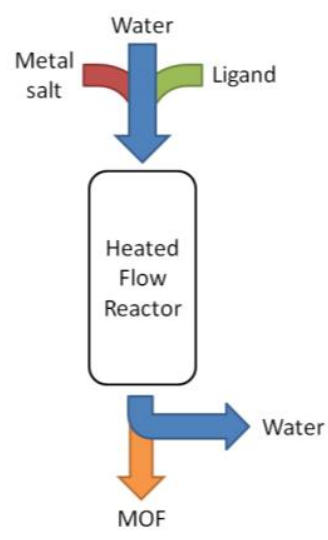




\section{Supplementary Information}

\section{Experimental Details}

A typical profile for $\mathrm{P}$ and $\mathrm{T}$ vs time for batch reactions is shown in Figure $\mathrm{S} 1$.

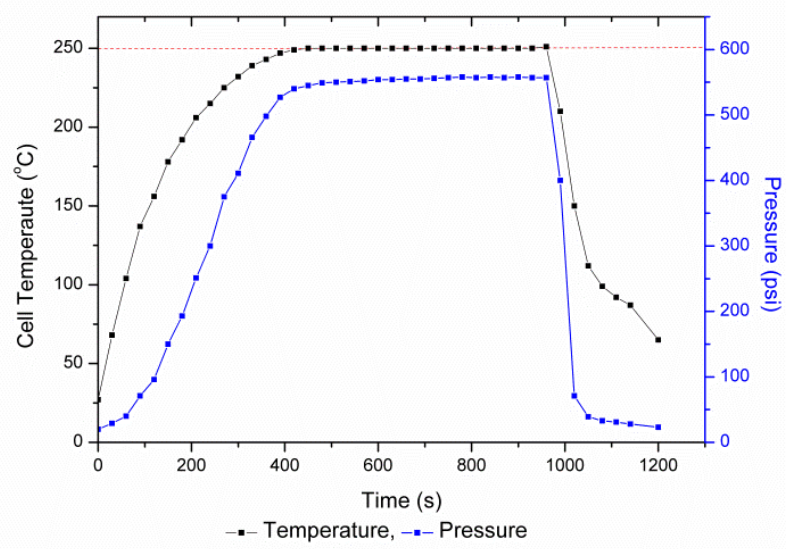

Figure S1 Plot of reactor internal temperature (black) and pressure (blue) against time for a typical batch reaction for $10 \mathrm{~min}$ at $250{ }^{\circ} \mathrm{C}$ to form MIL-53(Al). Red dotted line shows target reaction temperature.

Flow reactions: A back pressure regulator (BPR, Tescom, model no. 26-1762-24-043) was used in the flow systems (Figure 1). For the reactions carried out at $200{ }^{\circ} \mathrm{C}, 225{ }^{\circ} \mathrm{C}, 275^{\circ} \mathrm{C}$ and $300^{\circ} \mathrm{C}$ the same conditions as at $250{ }^{\circ} \mathrm{C}$ were used except the reactor heater was set to these temperatures. All yields are based on the target phase $\left[\mathrm{Al}(\mathrm{OH})\left(\mathrm{L}^{1}\right)\right]_{\mathrm{n}}$. The crude yield is quoted before removal of free $\mathrm{H}_{2} \mathrm{~L}^{1}$ for the pores; the pure yield refers to the overall yield after removal of in-pore $\mathrm{H}_{2} \mathrm{~L}^{1}$. The collection of samples at steady state also allows accurate determination of the yield, Y, using the equation:

$Y=\frac{m}{C_{L} F_{L} t M}$

where $m$ is mass collected, $t$ is time of collection, $C_{L}$ and $F_{L}$ are the molar concentration and flow rate of the ligand solution, respectively. $M$ is the molecular weight for $\left[\mathrm{Al}(\mathrm{OH})\left(\mathrm{C}_{6} \mathrm{H}_{4}\left(\mathrm{CO}_{2}\right)_{2}\right)\right]$.

scEtOH Extractions: As-synthesised MIL-53(Al) (100 mg) containing $\mathrm{H}_{2} \mathrm{~L}^{1}$ both internally in the pores and externally as discrete crystals was loaded into reactor 1 . The extraction was run for $2 \mathrm{hr}$ with reactor 1 held at $250{ }^{\circ} \mathrm{C}$ and reactor 2 cooled with water and with a liquid 
ethanol flow rate of $0.5 \mathrm{ml} \mathrm{min}^{-1}$ and a back pressure of 100 bar. Figure 2 shows a schematic of this extraction rig.

\section{Volumetric Gas Adsorption}

$\mathrm{N}_{2}$ isotherms were carried out on a Quantachrome Autosorb-1 (model no. As1-GYTKXL11, software ver. 1.61). Samples were degassed overnight, MIL-53(Al) material at $125^{\circ} \mathrm{C}$ and HKUST- 1 at $100^{\circ} \mathrm{C}$. The BET pressure range for the batch sample was $7.0 \times 10^{-3}$ to $2.9 \times$ $10^{-3} \mathrm{P} / \mathrm{P}_{0}$ and for the continuous process sample $2.5 \times 10^{-3}$ to $5.3 \times 10^{-2} \mathrm{P} / \mathrm{P}_{0}$, consistent with criteria used by Snurr and co-workers. ${ }^{1,2}$

\section{Gravimetric Gas adsorption}

$\mathrm{CO}_{2}$ and $\mathrm{CH}_{4}$ adsorption experiments were carried out using a Hiden Isochema Intelligent Gravimetric Analyzer (model no. IGA-003 system) at the University of Nottingham under ultra-high vacuum in a clean system with a diaphragm and turbo pumping system. IGASwin system software v.1.03.143 (Hiden Isochema, 2004) was used to fit all isotherm data points. All changes in sample weight were corrected for buoyancy effects.

\section{PXRD}

X-ray powder diffraction patterns were collected on a Pananalytical X'Pert Pro diffractometer operating at $160 \mathrm{~W}(40 \mathrm{kV}, 40 \mathrm{~mA}) \mathrm{Cu} K_{\alpha}(\lambda=1.5406 \AA)$ ). High resolution powder diffraction data were collected on Beamline I11 at Diamond Light Source using multi-analysing-crystal detectors (MACs) and an in situ gas cell system. ${ }^{3}$

TGA

Thermogravimetric analyses were performed on a Perkin Elmer Thermogravimetric analyzer Pyris 1 TGA (model no. R1R151 TGA, software Ver. 11.0.0.0449). A heating rate of $5{ }^{\circ} \mathrm{C}$ $\min ^{-1}$ was used from room temperature up to $700{ }^{\circ} \mathrm{C}$.

\section{Infrared (ATR-FTIR)}

Attenuated total reflectance (ATR) Fourier transformed Infrared (FTIR) was used to collect IR spectra for MOF samples. The data were collected using a Fisher Thermo Scientific Nicolet iS5 with iD5-ZnSe ATR attachment and Ominic (software ver. 8.2.0.387) using 16 scans with a data spacing of $0.482 \mathrm{~cm}^{-1}$ over a range of $600-4000 \mathrm{~cm}^{-1}$. 


\section{MIL-53(Al)}

The phase referred to as MIL-53(Al)op (CDS ref. code SABVUN) and MIL-53(Al)hy (CDS ref. code SABWAU) were first reported by Loiseau et al. ${ }^{4}$ The phase referred to as MIL-53(Al)ta (CDS ref. code SABVOH01) was reported by Vougo-Zanda et $a l,{ }^{5}$ and the phase referred to as $\mathrm{H}_{2} \mathrm{~L}^{1}$ (CDS ref. code TEPHTH) was first reported by Bailey and Brown, ${ }^{6}$ with the phase referred to as $\gamma-\mathrm{AlO}(\mathrm{OH})$ (ICSD collection code Collection Code 59609) reported by Bokhimi et al.. ${ }^{7}$ The simulated PXRD patterns were generated using Mercury 3.1 .8

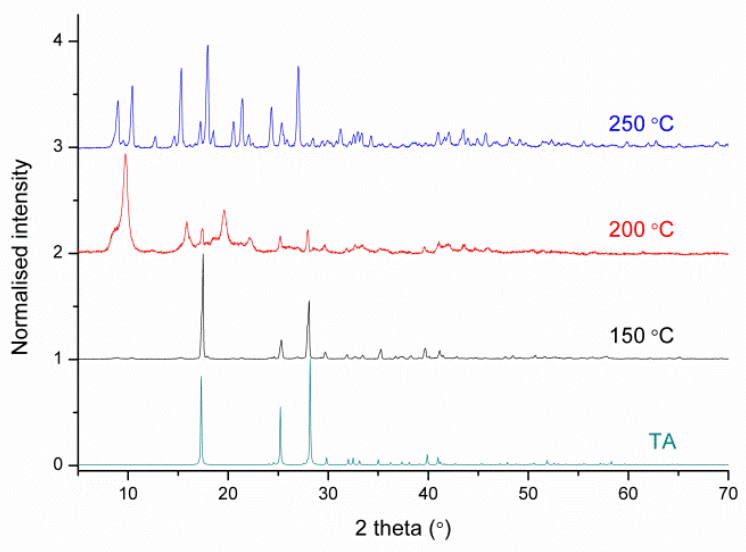

Figure S2 PXRD pattern of the reaction product MIL-53(Al) prepared by batch reaction at $150{ }^{\circ} \mathrm{C}$ (black), $200{ }^{\circ} \mathrm{C}$ (red) and $250{ }^{\circ} \mathrm{C}$ (blue) and simulated pattern for $\mathrm{H}_{2} \mathrm{~L}^{1}$ (green).

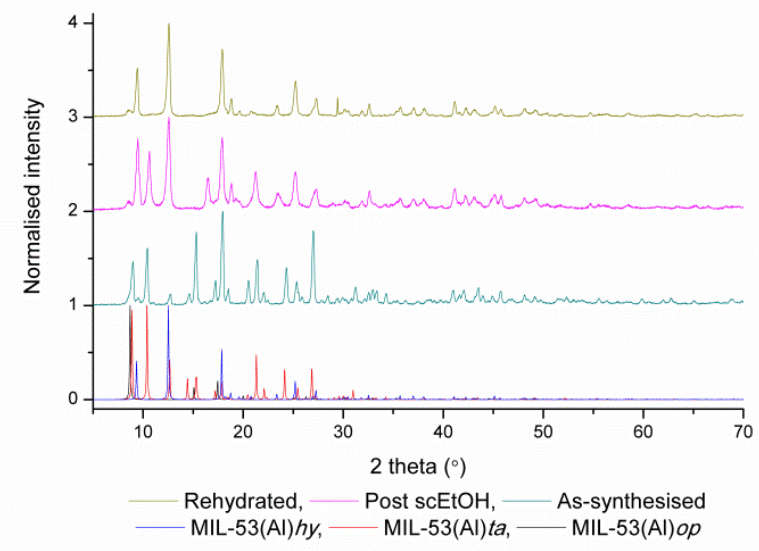

Figure S3 PXRD patterns for MIL-53(Al) produced in batch at $250{ }^{\circ} \mathrm{C}$; as-synthesised (green), after treatment with scEtOH (pink), and after degassing and rehydration (yellow). The rehydrated material can be seen to match MIL-53(Al) hydrate (blue) by comparison with the simulated pattern. The small shoulder on the first peak is due to incomplete rehydration. 


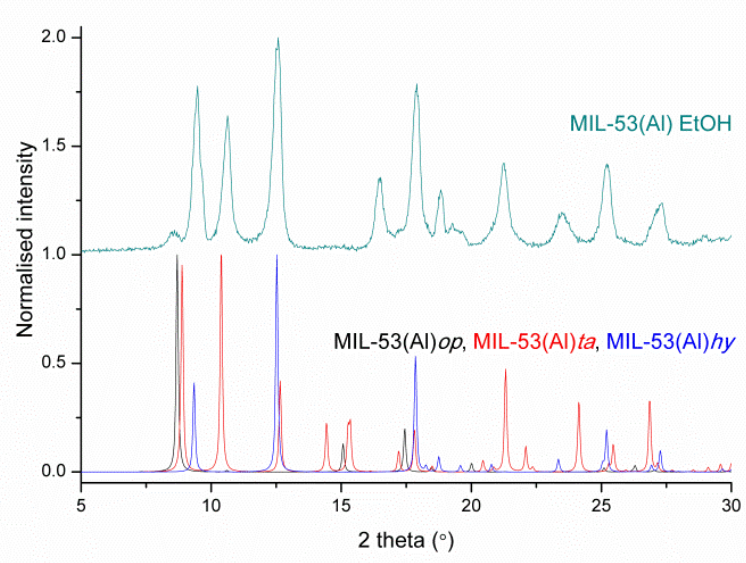

Figure S4 PXRD pattern of MIL-53(Al) after washing with scEtOH. The shift in peak positions and absence of peaks from $14-16^{\circ}$ confirms that this phase does not match previously reported phases, consistent with the formation of MIL-53(Al).xEtOH. MIL-53(Al) was produced in batch at $250{ }^{\circ} \mathrm{C}$, before being washed with scEtOH for $2 \mathrm{~h}$.

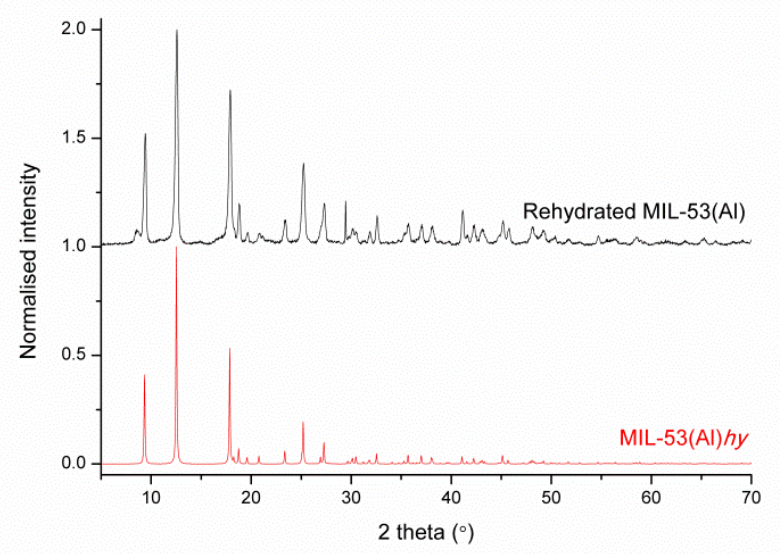

Figure S5 PXRD pattern of MIL-53(Al) prepared in batch $\left(250{ }^{\circ} \mathrm{C}\right)$, activated with scEtOH, degassed, and then and exposed to air (black). The sample matches the MIL-53(Al)hy (red).

Treatment of as-synthesised MIL-53(Al) with scEtOH produced new phases which do not match the known phases MIL-53(Al)ta, MIL-53(Al)hy or MIL-53(Al)op phase. Rehydration of the material affords MIL-53(Al) hydrate by comparison with the simulated pattern. The small shoulder on the first peak (Figure S6) is due to incomplete rehydration. None of the MIL-53(Al)ta phase is present after scEtOH treatment confirming that $\mathrm{H}_{2} \mathrm{~L}^{1}$ has been removed from the pores. 


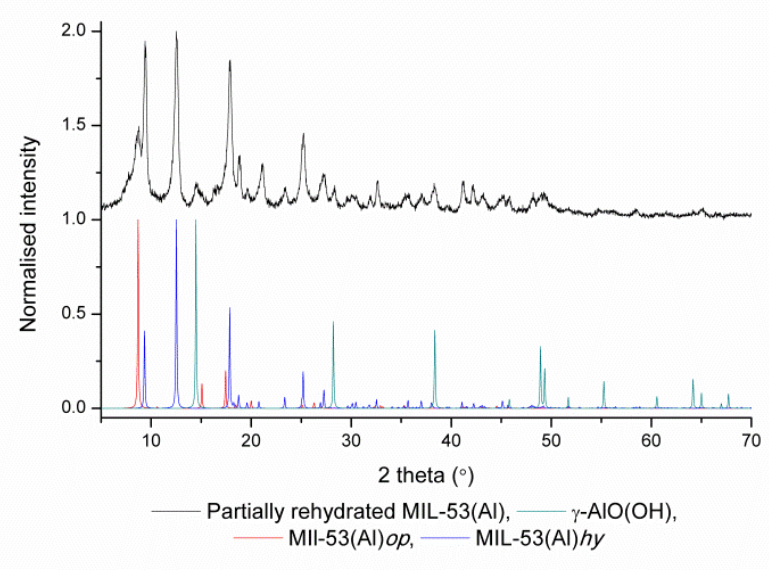

Figure S6 PXRD pattern of MIL-53(Al) prepared in continuousflow, treated with scEtOH, degassed and then partially rehydrated upon exposure to air (black). The sample matches the phases MIL-53(Al)op (red) and MIL-53(Al)hy (blue), and a minor phase $\gamma$-AlO(OH)(green) is present.

A Le Bail refinement was performed on PXRD data for the degassed sample of MIL-53(Al) produced in batch at $250{ }^{\circ} \mathrm{C}$. The refinement confirms that the bulk material matches with the known phase MIL-53(Al)op.

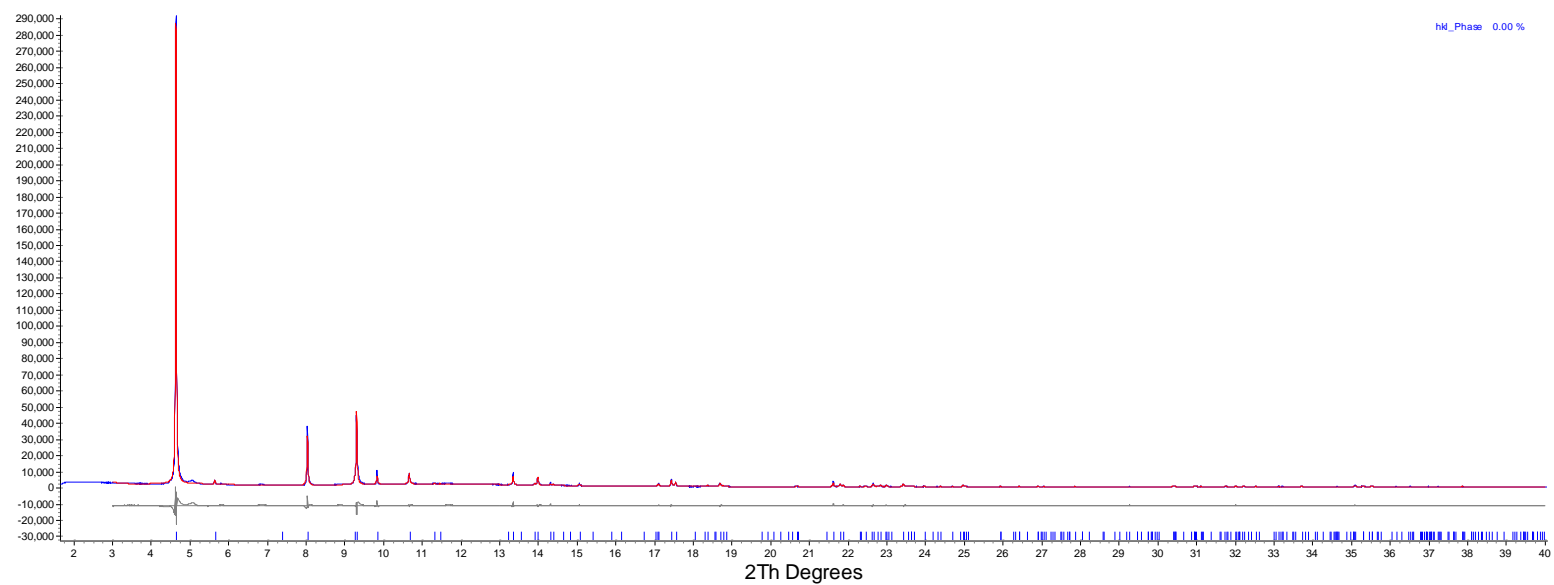

Figure S7 Le Bail profile fitting of MIL-53(Al) after degassing showing peaks at $2 \theta=0-40^{\circ}$ shown, r_wp $=9.06, \mathrm{r} \_\mathrm{p}=6.24$, gof $=5.53$, cell parameters: Imma, V = 1423.87(11), $a=$ $6.63198(25), b=16.75117(61), c=12.81691(69)$. The material was produced in batch at $250{ }^{\circ} \mathrm{C}$, treated with scEtOH, and degassed in situ. 


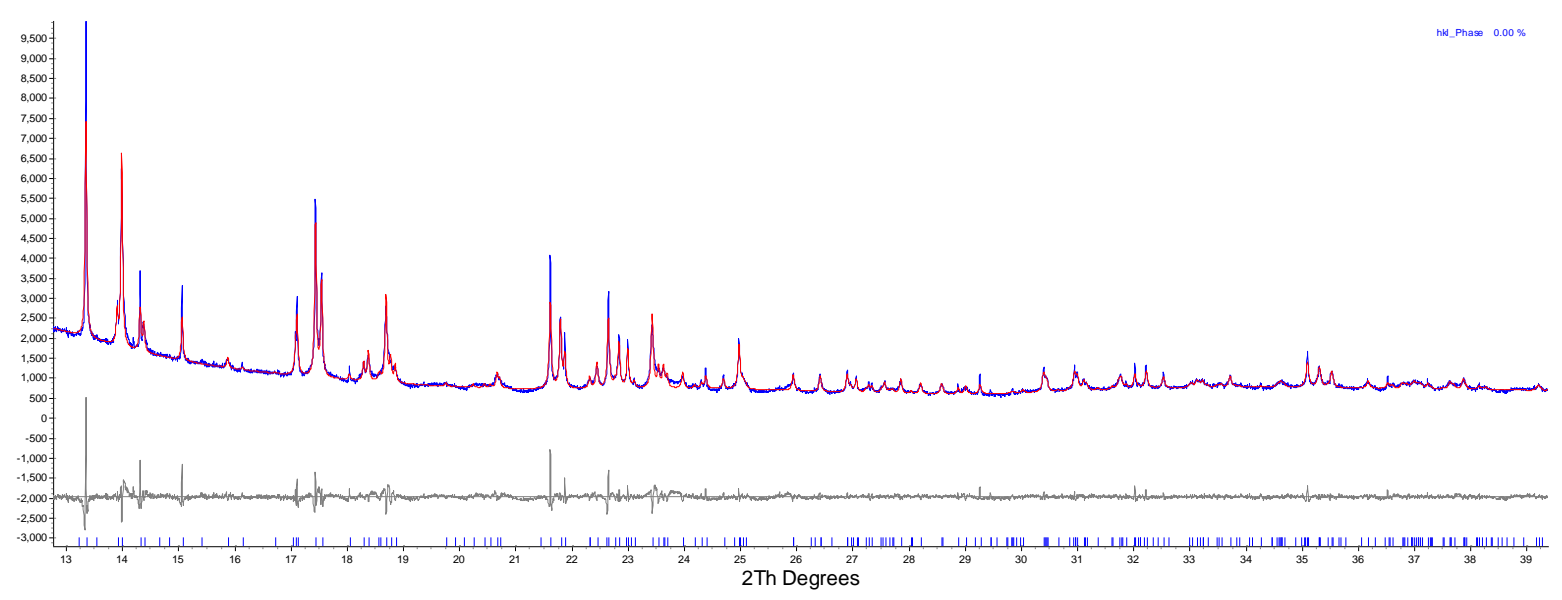

Figure S8 Le Bail profile fitting of PXRD data for MIL-53(Al) after degassing showing higher angle peaks with $2 \theta=13-39^{\circ}$.

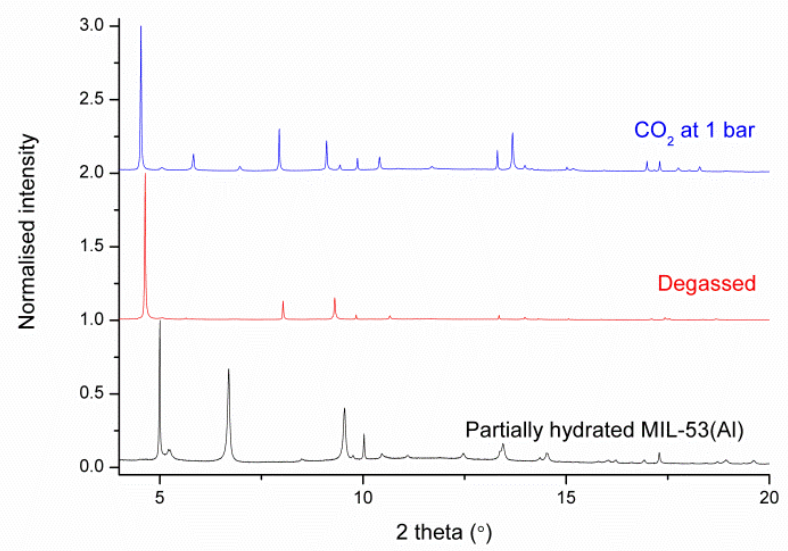

Figure S9 High resolution PXRD pattern $(\lambda=0.827107 \AA)$ of partially hydrated MIL-53(Al) (black), degassed in situ (red) and $\mathrm{CO}_{2}$ loading at 1 bar (blue). The material was produced in batch at $250{ }^{\circ} \mathrm{C}$ before treatment with scEtOH and drying. The PXRD data confirm that MIL-53(Al) exhibits the expected flexibility on degassing and $\mathrm{CO}_{2}$ adsorption. 


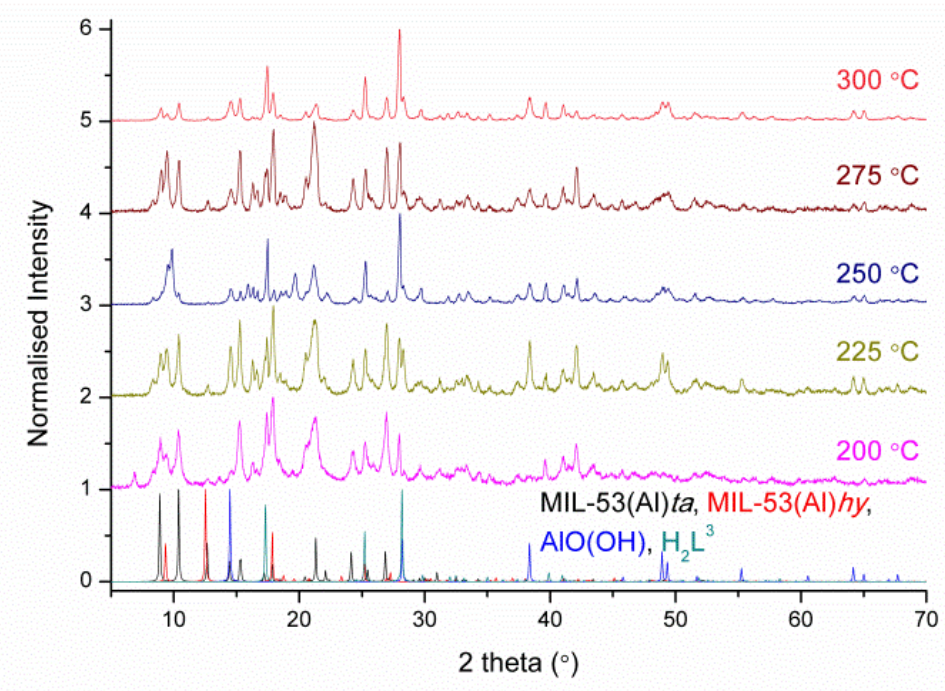

Figure S10 Comparison of PXRD patterns for products isolated from continuous flow reactions at $200{ }^{\circ} \mathrm{C}, 225{ }^{\circ} \mathrm{C}, 250{ }^{\circ} \mathrm{C}, 275^{\circ} \mathrm{C}$ and $300{ }^{\circ} \mathrm{C}$. PXRD patterns for MIL-53(Al)ta, MIL-53(Al)hy, $\mathrm{H}_{2} \mathrm{~L}^{1}$ and $\mathrm{AlO}(\mathrm{OH})$ are shown for comparison.

In the TGA for $\left[\mathrm{Al}(\mathrm{OH})\left(\mathrm{L}^{1}\right)+\mathrm{xH}_{2} \mathrm{~L}^{1}\right]_{\mathrm{n}}$, the step of $38.5 \%$ between $215^{\circ} \mathrm{C}$ and $440^{\circ} \mathrm{C}$ is attributed to the loss of in-pore $\mathrm{H}_{2} \mathrm{~L}^{1}$ (Figure S11). From this it has been calculated the assynthesised product contains 0.8 equivalents of $\mathrm{H}_{2} \mathrm{~L}^{1}$. The step of $39.2 \%$ from $540{ }^{\circ} \mathrm{C}$ to $665{ }^{\circ} \mathrm{C}$ corresponds to loss of terephthalate linker and structure decomposition of the framework to aluminium oxide. For as-synthesised MIL-53(Al) Loiseau et al reported two steps in the range of $275-420{ }^{\circ} \mathrm{C}$ for the sublimation of $\mathrm{H}_{2} \mathrm{~L}^{1}$ removal and the loss of $0.7 \mathrm{H}_{2} \mathrm{~L}^{1}$ equivalents. ${ }^{3}$ Here the additional steps between $200-300{ }^{\circ} \mathrm{C}$ may also include direct sublimation of amorphous $\mathrm{H}_{2} \mathrm{~L}^{1}$ located outside of the pores. This is plausible since we have used a higher $\mathrm{H}_{2} \mathrm{~L}^{1}$ : Al ratio in the synthesis of the material. 


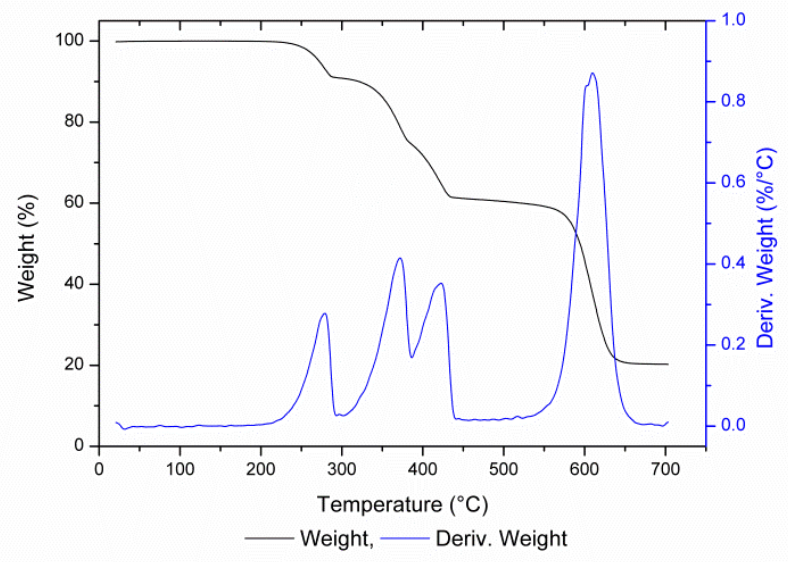

Figure S11 TGA of the as-synthesised batch sample $\left[\mathrm{Al}(\mathrm{OH})\left(\mathrm{L}^{1}\right)+0.8 \mathrm{H}_{2} \mathrm{~L}^{1}\right]_{\mathrm{n}}$ (black) with derivative plot (blue) showing the rate of change of \% weight loss with temperature.

TGA for the as-synthesised MIL-53(Al) from the continuous flow process has a step of $23.6 \%$ between $215^{\circ} \mathrm{C}$ and $440{ }^{\circ} \mathrm{C}$ attributed to the loss of in-pore $\mathrm{H}_{2} \mathrm{~L}^{1}$ and is divided into three steps (Figure S12). From this it has been calculated that the as-synthesised product contains $0.41 \mathrm{H}_{2} \mathrm{~L}^{1}$ equivalents. The step of $36.4 \%$ from $500{ }^{\circ} \mathrm{C}$ to $690{ }^{\circ} \mathrm{C}$ corresponds to loss of ligand and structure decomposition of the framework to aluminium oxide.

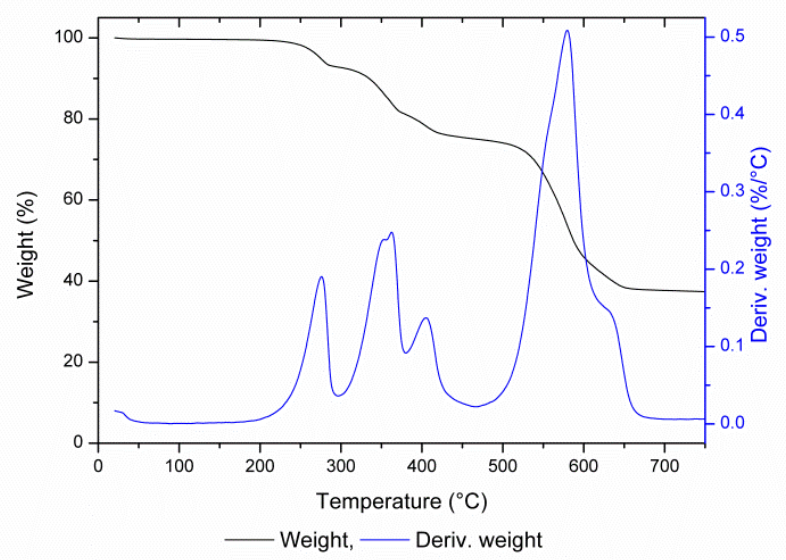

Figure S12 TGA under $\mathrm{N}_{2}$ of as-synthesised MIL-53(Al) produced using the continuous flow process; the derivative plot (blue) shows the rate of change of $\%$ weight loss with temperature. 


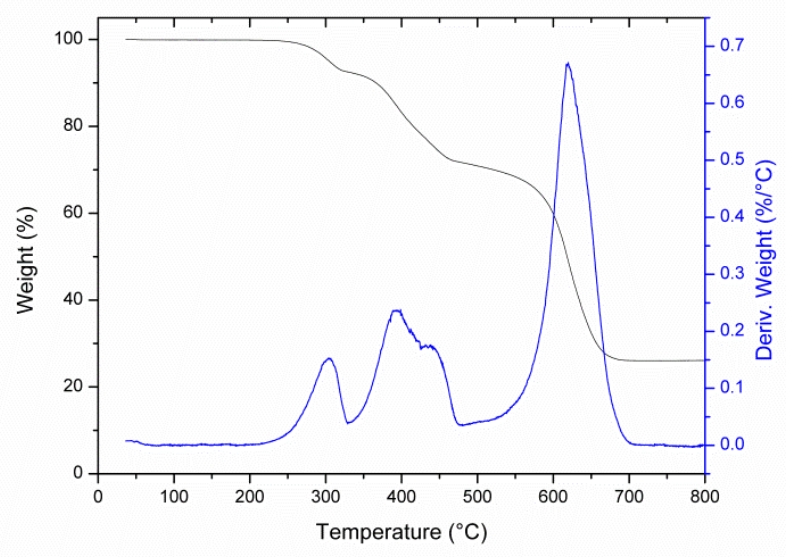

Figure S13 TGA under air of as-synthesised MIL-53(Al) produced using the continuous flow process; the derivative plot (blue) shows the rate of change of $\%$ weight loss with temperature.

The TGA for MIL-53(Al) produced in batch at $250{ }^{\circ} \mathrm{C}$ after treatment with scEtOH has an initial weight loss of $6.0 \%$ between $15^{\circ} \mathrm{C}$ at $100{ }^{\circ} \mathrm{C}$ corresponding to loss of ethanol trapped in the pores (Figure S14). The TGA shows a weight loss of only $2.4 \%$ in the region of $215^{\circ} \mathrm{C}$ to $475^{\circ} \mathrm{C}$, confirming that in-pore $\mathrm{H}_{2} \mathrm{~L}^{1}$ has been removed. The second step of $63.6 \%$ between $500{ }^{\circ} \mathrm{C}$ and $700{ }^{\circ} \mathrm{C}$ is due to the decomposition of the material.

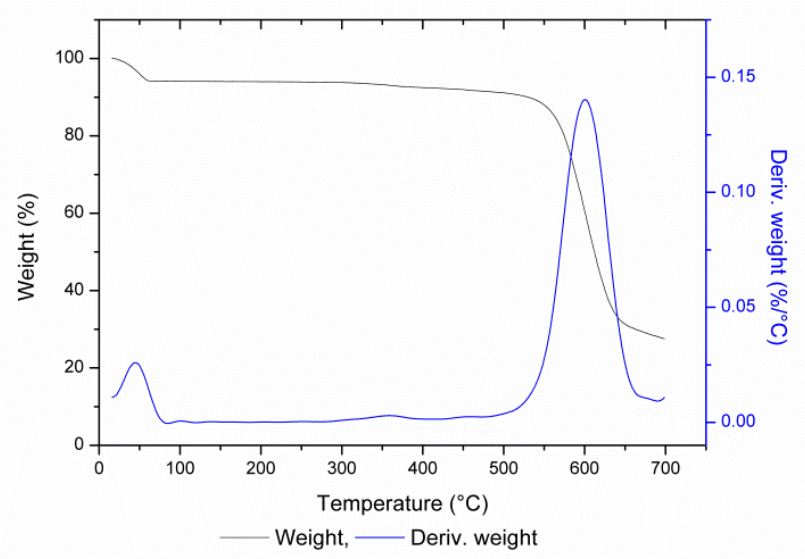

Figure S14 TGA of MIL-52(Al) produced in batch after treatment with scEtOH to remove uncoordinated $\mathrm{H}_{2} \mathrm{~L}^{1}$ from within the pores. 


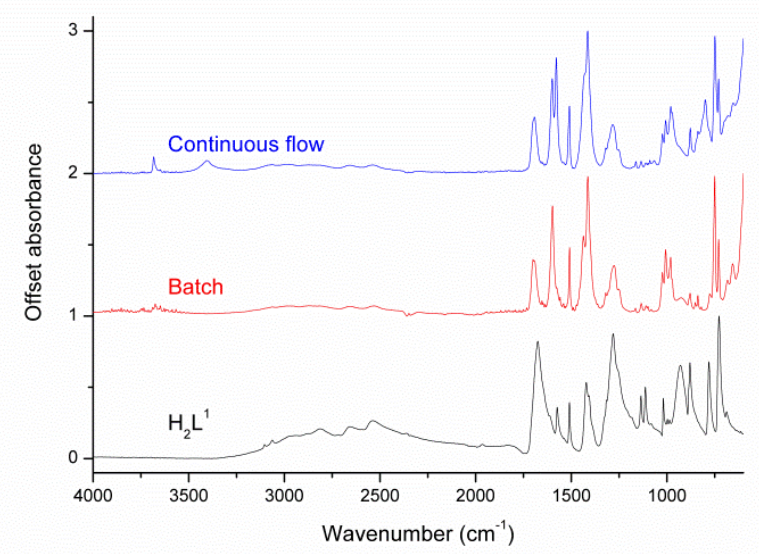

Figure S15 ATR-FTIR of MIL-53(Al) synthesised using HTW at $250{ }^{\circ} \mathrm{C}$ via batch (red) and continuous flow process (blue) and of $\mathrm{H}_{2} \mathrm{~L}^{1}$ (black) for comparison.

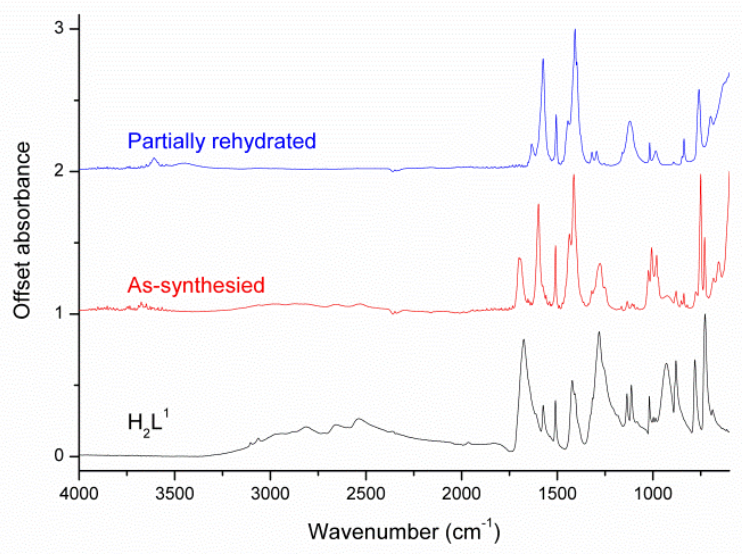

Figure S16 ATR-FTIR of MIL-53(Al) produced in batch; the as-synthesised (red) and partially rehydrated sample (blue). The partially rehydrated sample was first treated with scEtOH to remove $\mathrm{H}_{2} \mathrm{~L}^{1}$ from the pores, followed by degassing at $120{ }^{\circ} \mathrm{C}$ overnight and then partial rehydration on exposure to air. The absence of the peak at $1695 \mathrm{~cm}^{-1}$ (uncoordinated) confirms that $\mathrm{H}_{2} \mathrm{~L}^{1}$ is no longer present in the pores. The FTIR spectrum of $\mathrm{H}_{2} \mathrm{~L}^{1}$ is shown for comparison. 


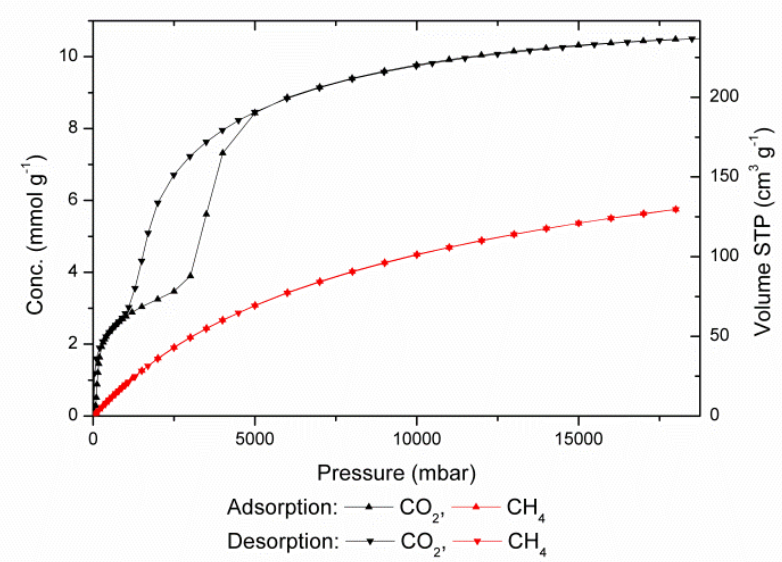

Figure $\mathrm{S17} \mathrm{CO}_{2}$ and $\mathrm{CH}_{4}$ isotherms at $10{ }^{\circ} \mathrm{C}$ for MIL-53(Al) produced in batch at $250{ }^{\circ} \mathrm{C}$. The higher uptake of $\mathrm{CO}_{2}$ indicates selectivity for $\mathrm{CO}_{2}$ over $\mathrm{CH}_{4}$.

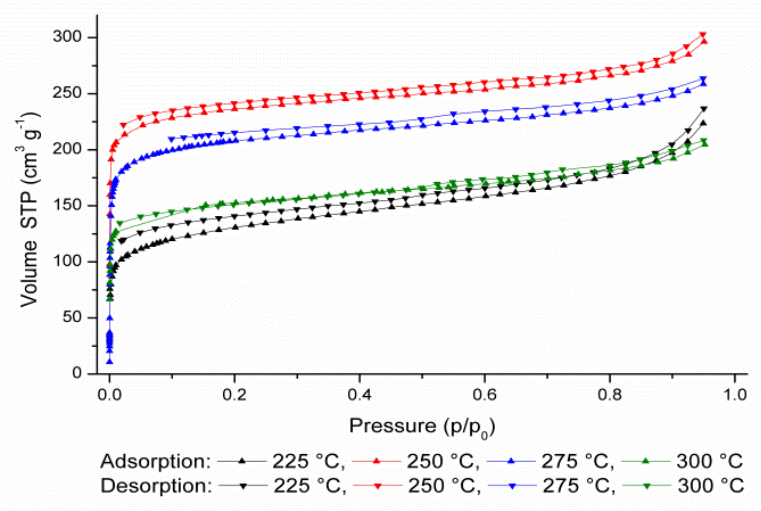

Figure S18 $\mathrm{N}_{2}$ isotherms at $77 \mathrm{~K}$ for products of continuous flow reactions at $225^{\circ} \mathrm{C}$, $250{ }^{\circ} \mathrm{C}, 275^{\circ} \mathrm{C}$ and $300{ }^{\circ} \mathrm{C}$. Prior to gas adsorption scEtOH treatment was used to remove unreacted $\mathrm{H}_{2} \mathrm{~L}^{1}$. Note that the yield of the reaction at $200{ }^{\circ} \mathrm{C}$ was too low to produce sufficient material for gas adsorption.

Independent measurements of the surface area and uptake of $\mathrm{N}_{2}$ for the material produced by scaling up the reaction and for the commercial sample were performed by MCA Services, Unit 1A, Long Barn, North End, Meldreth, Cambs, SG8 6NT, UK. The results show our scale-up sample had a BET surface area of $1010 \mathrm{~m}^{2} \mathrm{~g}^{-1}$ and the commercial sample $553 \mathrm{~m}^{2} \mathrm{~g}^{-1}$. 


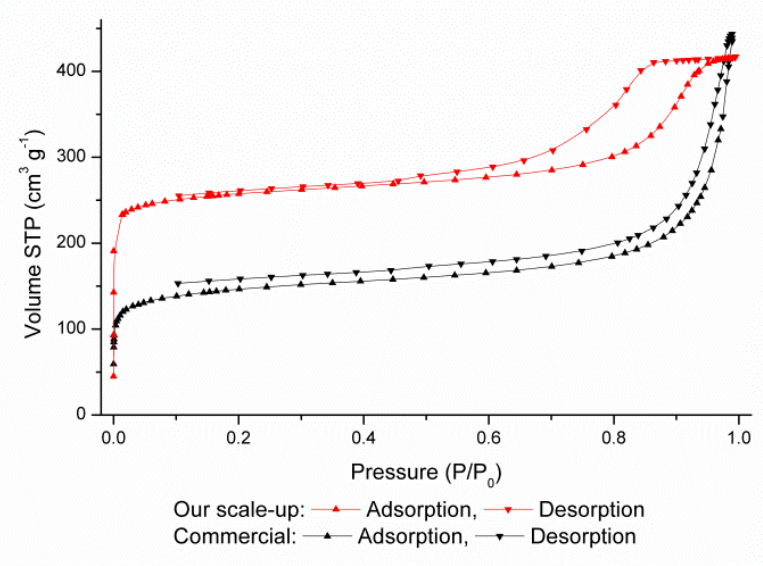

Figure S19 $\mathrm{N}_{2}$ isotherm at $77 \mathrm{~K}$ for our scaled-up sample of MIL-53(Al) and for a commercial sample. Uncoordinated $\mathrm{H}_{2} \mathrm{~L}^{1}$ was removed from the scale-up sample by heating at $330{ }^{\circ} \mathrm{C}$ for 3 days.

\section{HKUST-1}

The synthesis of $\left[\mathrm{Cu}_{3}\left(\mathrm{~L}^{2}\right)_{2}\right]_{\mathrm{n}}$, HKUST-1, was achieved using the same procedure as with MIL-53(Al) except EtOH was used in place of water. Since both trimesic acid $\left(\mathrm{H}_{3} \mathrm{~L}^{2}\right)$ and $\mathrm{Cu}\left(\mathrm{NO}_{3}\right)_{2}$ are soluble in EtOH the use of ligand salts was not required. Thus, treatment of $\mathrm{Cu}\left(\mathrm{NO}_{3}\right)_{2} \cdot 3 \mathrm{H}_{2} \mathrm{O}(86.2 \mathrm{mg}, 0.357 \mathrm{mmol})$ with $\mathrm{H}_{3} \mathrm{~L}^{2}(50.0 \mathrm{mg}, 0.238 \mathrm{mmol})$ in EtOH $(5.0 \mathrm{ml})$ at $200{ }^{\circ} \mathrm{C}$ for 10 minutes afforded a material the PXRD of which matches that of HKUST-1 (Figure S16). No free $\mathrm{H}_{3} \mathrm{~L}^{2}$ was recovered with the material and so a further purification step was not necessary. The material produced by continuous process had a surface area of $1554 \mathrm{~m}^{2} \mathrm{~g}^{-1}$, a maximum nitrogen uptake of $416.9 \mathrm{~cm}^{3} \mathrm{~g}^{-1}\left(0.95 \mathrm{P} / \mathrm{P}_{0}\right)$, and a pore volume of $0.62 \mathrm{~cm}^{3} \mathrm{~g}^{-1}$. The space time yield of HKUST-1 in this process was $730 \mathrm{~kg} \mathrm{~m}^{-3} \mathrm{~d}^{-1}$.

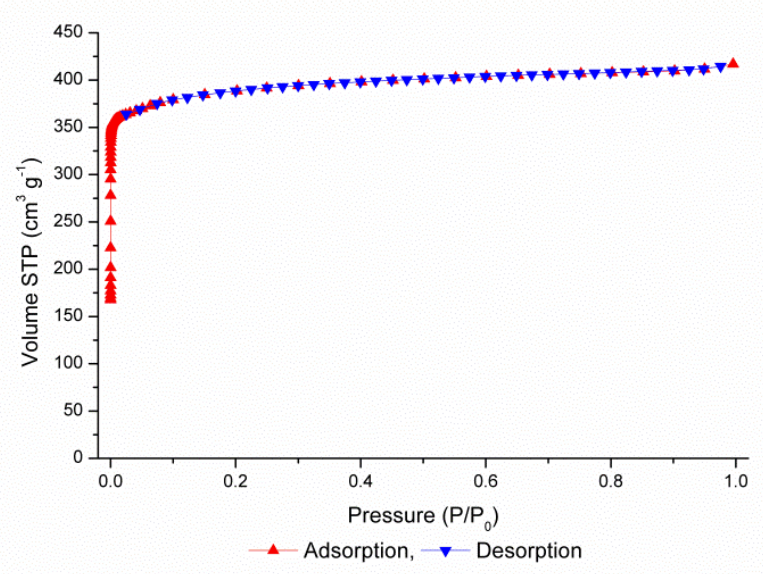

Figure $\mathbf{S 2 0 ~} \mathrm{N}_{2}$ gas sorption isotherm of HKUST-1 prepared by continuous flow reaction in EtOH at $200{ }^{\circ} \mathrm{C}$. 
The TGA for as-synthesised HKUST-1 produced by continuous flow exhibits the expected thermal behaviour with three steps (Figure S21). The first of $11.4 \%$ between 20 and $70{ }^{\circ} \mathrm{C}$ is the result of loss of EtOH from the pores. The second step of $19.7 \%$ between $70{ }^{\circ} \mathrm{C}$ and $220{ }^{\circ} \mathrm{C}$ is attributed to the loss of coordinated solvents with a total solvent loss of $31.1 \%$. The third step of $30.7 \%$ between $295^{\circ} \mathrm{C}$ and $450{ }^{\circ} \mathrm{C}$ corresponds to decomposition of the material.

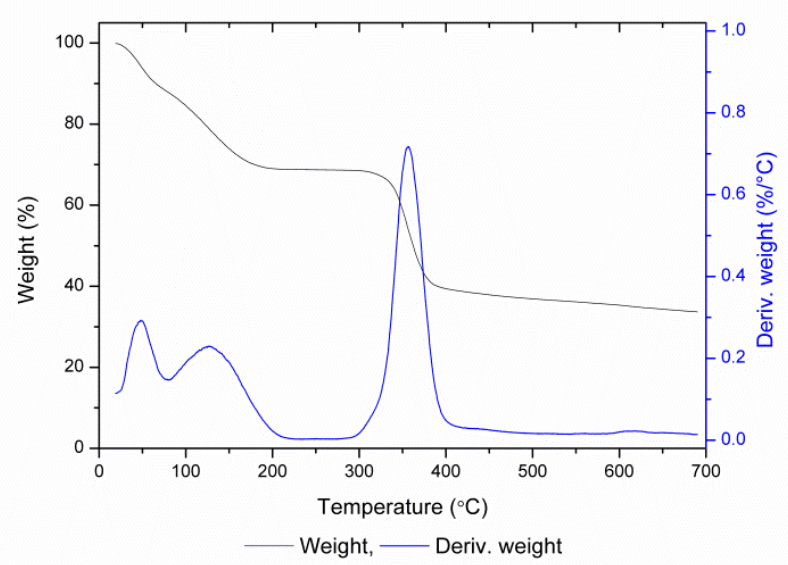

Figure S21 TGA of as-synthesised HKUST-1 prepared by continuous flow (black); the first derivative plot (blue) shows the rate of change of \% weight loss with temperature.

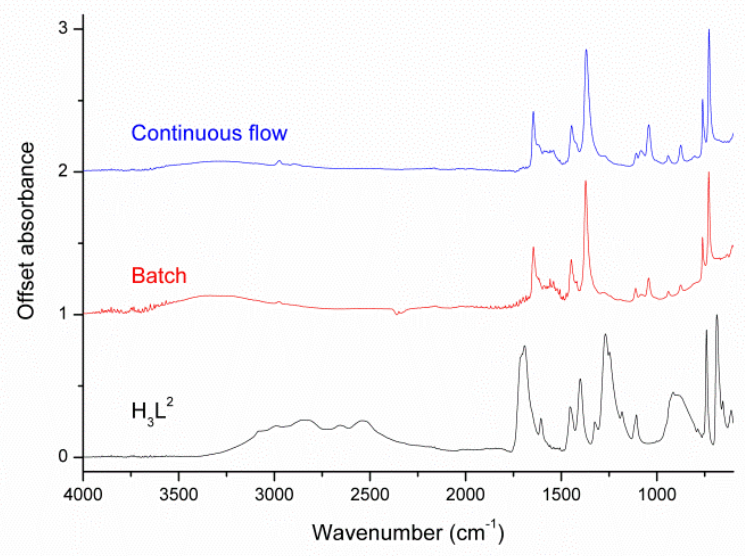

Figure S22 ATR-FTIR of as-synthesised of HKUST-1 via batch (red) and continuous flow process (blue) using EtOH at $200{ }^{\circ} \mathrm{C}$, and of trimesic acid $\mathrm{H}_{3} \mathrm{~L}^{2}$ (black).

\section{References}

1. K. S. Walton and R. Q. Snurr, J. Am. Chem. Soc., 2007, 129, 8552-8556.

2. Y.-S. Bae, A. O. z. r. Yazaydın and R. Q. Snurr, Langmuir, 2010, 26, 5475-5483. 
3. S. P. Thompson, J. E. Parker, J. Potter, T. P. Hill, A. Birt, T. M. Cobb, F. Yuan and C. C. Tang, Review of Scientific Instruments, 2009, 80, 075107.

4. T. Loiseau, C. Serre, C. Huguenard, G. Fink, F. Taulelle, M. Henry, T. Bataille and G. Férey, Chemistry-Eur. J., 2004, 10, 1373-1382.

5. M. Bailey and C. J. Brown, Acta Cryst., 1967, 22, 387-391.

6. M. Vougo-Zanda, J. Huang, E. Anokhina, X. Wang and A. J. Jacobson, Inorg. Chem., 2008, 47, 11535-11542.

7. X. Bokhimi, J. Sánchez-Valente and F. Pedraza, J. Solid State Chem., 2002, 166, 182-190.

8. C. F. Macrae, I. J. Bruno, J. A. Chisholm, P. R. Edgington, P. McCabe, E. Pidcock, L. Rodriguez-Monge, R. Taylor, J. van de Streek and P. A. Wood, J. App. Cryst., 2008, 41, 466470.

9. S. S.-Y. Chui, S. M.-F. Lo, J. P. H. Charmant, A. G. Orpen and I. D. Williams, Science, 1999, 283, 1148-1150.

10. R. Ameloot, F. Vermoortele, W. Vanhove, M. B. J. Roeffaers, B. F. Sels and D. E. De Vos, Nature Chem., 2011, 3, 382-387.

11. M. Gimeno-Fabra, A. S. Munn, L. A. Stevens, T. C. Drage, D. M. Grant, R. J. Kashtiban, J. Sloan, E. Lester and R. I. Walton, ChemComm., 2012, 48, 10642-10644.

12. K.-J. Kim, Y. J. Li, P. B. Kreider, C.-H. Chang, N. Wannenmacher, P. K. Thallapally and H.G. Ahn, ChemComm., 2013, 49, 11518-11520.

13. M. Hartmann, S. Kunz, D. Himsl, O. Tangermann, S. Ernst and A. Wagener, Langmuir, 2008, 24, 8634-8642. 